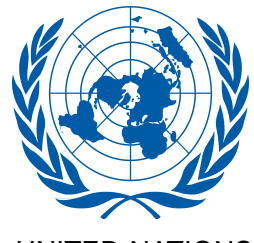

INTERNATIONAL

DEVELOPMENT

HARVARD UNIVERSITY

\title{
Competition and Competition Policy in Emerging Markets: International and Developmental Dimensions
}

\author{
Ajit Singh
}

No. 18, September 2002 
UNITED NATIONS CONFERENCE ON

TRADE AND DEVELOPMENT
CENTER FOR INTERNATIONAL DEVELOPMENT

HARVARD UNIVERSITY

\section{G-24 Discussion Paper Series}

Research papers for the Intergovernmental Group of Twenty-Four on International Monetary Affairs

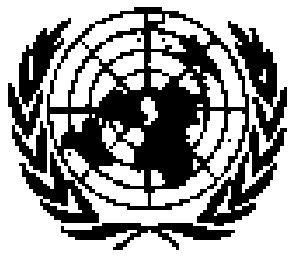

UNITED NATIONS

New York and Geneva, September 2002 


\section{Note}

Symbols of United Nations documents are composed of capital letters combined with figures. Mention of such a symbol indicates a reference to a United Nations document.

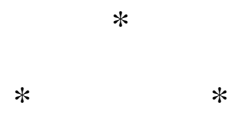

The views expressed in this Series are those of the authors and do not necessarily reflect the views of the UNCTAD secretariat. The designations employed and the presentation of the material do not imply the expression of any opinion whatsoever on the part of the Secretariat of the United Nations concerning the legal status of any country, territory, city or area, or of its authorities, or concerning the delimitation of its frontiers or boundaries.

Material in this publication may be freely quoted; acknowledgement, however, is requested (including reference to the document number). It would be appreciated if a copy of the publication containing the quotation were sent to the Publications Assistant, Macroeconomic and Development Policies Branch, Division on Globalization and Development Strategies, UNCTAD, Palais des Nations, CH-1211 Geneva 10.

UNCTAD/GDS/MDPB/G24/18

UNITED NATIONS PUBLICATION

Copyright $\odot$ United Nations, 2002 All rights reserved 


\section{PREFACE}

The G-24 Discussion Paper Series is a collection of research papers prepared under the UNCTAD Project of Technical Support to the Intergovernmental Group of Twenty-Four on International Monetary Affairs (G-24). The G-24 was established in 1971 with a view to increasing the analytical capacity and the negotiating strength of the developing countries in discussions and negotiations in the international financial institutions. The G-24 is the only formal developing-country grouping within the IMF and the World Bank. Its meetings are open to all developing countries.

The G-24 Project, which is administered by UNCTAD's Macroeconomic and Development Policies Branch, aims at enhancing the understanding of policy makers in developing countries of the complex issues in the international monetary and financial system, and at raising awareness outside developing countries of the need to introduce a development dimension into the discussion of international financial and institutional reform.

The research carried out under the project is coordinated by Professor Dani Rodrik, John F. Kennedy School of Government, Harvard University. The research papers are discussed among experts and policy makers at the meetings of the G-24 Technical Group, and provide inputs to the meetings of the G-24 Ministers and Deputies in their preparations for negotiations and discussions in the framework of the IMF's International Monetary and Financial Committee (formerly Interim Committee) and the Joint IMF/ IBRD Development Committee, as well as in other forums. Previously, the research papers for the G-24 were published by UNCTAD in the collection International Monetary and Financial Issues for the 1990s. Between 1992 and 1999 more than 80 papers were published in 11 volumes of this collection, covering a wide range of monetary and financial issues of major interest to developing countries. Since the beginning of 2000 the studies are published jointly by UNCTAD and the Center for International Development at Harvard University in the G-24 Discussion Paper Series.

The Project of Technical Support to the G-24 receives generous financial support from the International Development Research Centre of Canada and the Government of Denmark, as well as contributions from the countries participating in the meetings of the G-24. 


\title{
COMPETITION AND COMPETITION POLICY IN EMERGING MARKETS: INTERNATIONAL AND DEVELOPMENTAL DIMENSIONS
}

\author{
Ajit Singh \\ Professor of Economics, University of Cambridge \\ Senior Fellow, Queens' College, Cambridge Faculty \\ of Economics and Politics, University of Cambridge
}

G-24 Discussion Paper No. 18

September 2002 


\begin{abstract}
This paper examines the role of competition policy in emerging markets from a developmental and international perspective. The main issues addressed include the following:

- The state of competition and competition policy in developing countries;

- The relationship between competition, competition policy and economic development;

- The implications of the recent new advances in the theory of industrial organization for competition policy;

- The current international merger wave and its impact on developing countries;

- Multilateral competition policy and the establishment of an International Competition Authority (ICA).
\end{abstract}

The paper's main conclusions include the following:

- Contrary to conventional wisdom, many different kinds of evidence suggest that the intensity of competition in leading emerging markets is certainly no less, if not greater, than that observed in advanced countries.

- Analysis and evidence indicates that maximum competition is not necessarily optimal, in terms of dynamic efficiency, i.e. maximization of an economy's long-term productivity growth.

- Even if it was not required in the past, developing countries need a competition policy today, because of the huge international merger movement as well as privatization and deregulation in these economies themselves.

- There is little evidence to indicate that the current international merger wave will enhance global economic efficiency. Giant cross-border mergers, as well as those occurring between large firms within advanced countries, could, however, adversely affect competition and contestability in developing countries and the world economy. Even with competition policies, developing countries may not be able to restrain anticompetitive behaviour by large multinationals.

- The current competition policies in the United States and the European Union are unsuitable for developing countries. Countries at different levels of development and governance capacities require different types of competition policies. A good model for many emerging countries with effective governance structures is that of the Japanese competition policy during 1950-1973. The Japanese used both competition and cooperation to promote rapid industrialization.

The paper presents a proposal for a development-oriented international competition authority to control anti-competitive conduct and growth by mergers of large multinationals. It is argued here that the current discourse on the development dimension of competition policy at the WTO is unsatisfactory; its terms and language need to be radically changed. The ultimate aim of the WTO should not be to promote free trade for its own sake, but to achieve economic development. 


\section{Table of contents}

\section{Preface} iii

Abstract vii

I. Introduction: competition policy and developing countries - the international context ........ 1

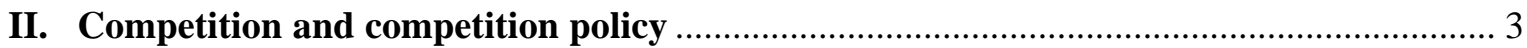

A. Competition and competition policy in emerging markets ........................................... 3

B. Competition, competition policy and economic development .......................................... 7

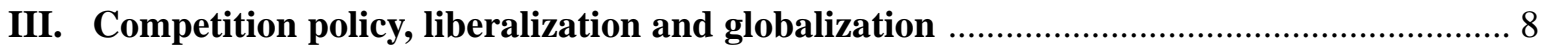

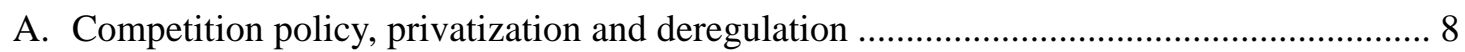

B. The international merger wave and competition policy in developing countries ............... 9

IV. Competition policy and developing countries:

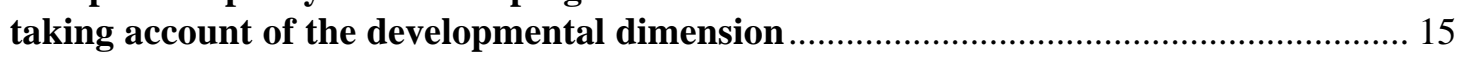

A. Competition policy and development: analytical considerations .................................... 15

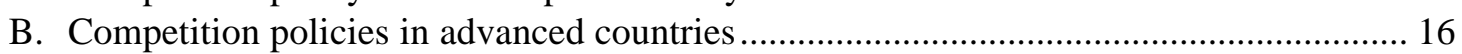

C. New concepts for competition policy for economic development ................................. 18

V. Multilateral competition policy versus international competition authority .................. 18

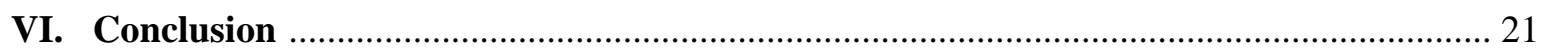

Notes

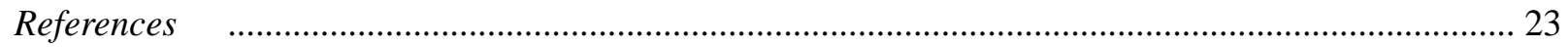

\section{List of tables}

1 Concentration ratios in emerging markets

2 Distribution of employment shares for small enterprises in developing countries

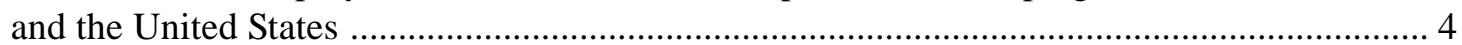

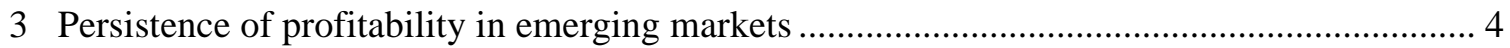

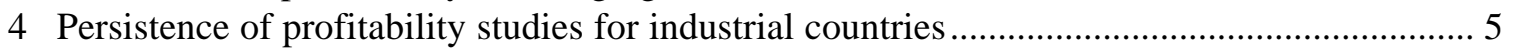

5 Plant and job turnover in developing versus developed countries ......................................... 5

6 Number of developing countries that have adopted competition laws,

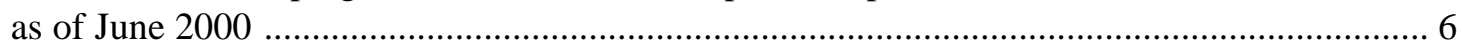

7 Benchmarks of product market dominance in competition laws around the world .................. 7

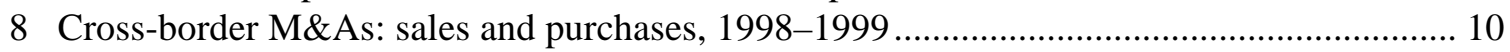

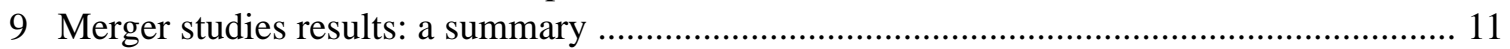

10 Cross-border deals, horizontal and conglomerate mergers by country groupings .................. 13

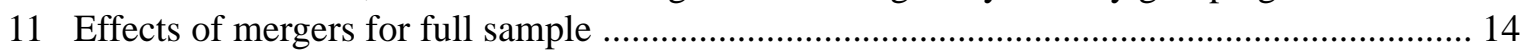

12 Japanese cartel agreements exempted from the anti-monopoly law by the Fair Trade Commission or the competent ministry by exempting statute, 1964-1973 


\title{
COMPETITION AND COMPETITION POLICY IN EMERGING MARKETS: INTERNATIONAL AND DEVELOPMENTAL DIMENSIONS
}

\author{
Ajit Singh*
}

\section{Introduction: competition policy and developing countries - the international context}

Developing countries are today faced with a range of new issues related to the microeconomic behaviour of economic agents - individuals, households and corporations - in these societies. In the past such behaviour, and a country's institutional arrangements which supported it, have been the prerogatives of sovereign nation states. However, with liberalization and globalization these matters are today regarded as legitimate objects of attention by the international community. Hence, under the new International Financial Architecture which is being constructed following the Asian crisis, emerging countries are being asked to reform their systems of corporate governance, labour laws, competition policy and other similar institutional structures. With respect to competition policy, which is the subject of this paper, it is suggested by many policy makers that not only do developing countries require a competition policy, but a multilateral one would be greatly to their advantage.

The main purpose of this paper is to brief developing countries on the complexities of this issue as well as its important policy implications for economic development. The paper will examine the virtues and limitations of both national and international competition policies.

Contrary to the wishes of developing countries, the so-called "Singapore issues" were included in the WTO's November 2001 Doha Declaration of Ministers: these are investment, competition policy, trade facilitation and government procurement. Competition policy was put on the agenda at the Singapore Ministerial meeting in 1996 as part of a review of the relationship between trade and investment. As this topic was being included in the WTO's work program - even at that time over the objections of developing countries - it was agreed that

\footnotetext{
* This is a revised version of a paper originally presented at the meeting of the G-24 Technical Group held in Beirut in March, 2002. I am grateful to Dani Rodrik and to other participants for constructive comments. I am also grateful to Benjamin Wheeler and Ann Zammit for their help in preparing the paper. I alone am responsible for any errors.
} 
the matter should be studied by a working group with a remit to pay particular attention to the development dimension of competition policy. This was to be without prejudice to the question of any prospective negotiations on the subject. ${ }^{1}$ However, five years later at Doha, in one of the more confusing paragraphs of the Declaration, Ministers "agreed that negotiations will take place after the fifth Session of the Ministerial Conference on the basis of a decision to be taken, by explicit consensus, at that Session on modalities of negotiations." Many, but by no means all, ${ }^{2}$ developed countries consider this as a mandate to launch negotiations at the fifth Ministerial in 2003 or shortly thereafter, whereas most developing countries maintain that the negotiations may be years off, as a decision to launch them must be taken by "explicit consensus". Much of this divergence arises from the undefined word "modalities", which countries choose to interpret in different ways. $^{3}$

At India's request, Yussef Hussain Kamal, the Conference Chair at Doha, presented the following clarification: "In my view, this would give each Member the right to take a position on modalities that would prevent negotiations from proceeding after the fifth Session of the Ministerial Conference until that Member is prepared to join in an explicit consensus." As the clarification seems to express only a personal view, the legal status of the Chair's statement remains unclear. It is not formally attached to the Ministerial Declaration itself, but forms part of the official Conference proceedings.

Be that as it may, it is quite clear that sooner or later developing countries will need to be ready to enter into discussions or negotiations with advanced countries with respect to competition policy at the WTO as well as other multilateral, regional or bilateral fora. ${ }^{4}$ International concern about the state of competition and competition policy in emerging countries precedes and goes beyond the Doha Declaration. This is because these issues also derive their international significance from some important analyses of the Asian financial crisis of 1997-1998 and the subsequent proposals on the New International Financial Architecture. Competition and competition policy figure prominently in these designs for a new architecture for the global economic system. This is due to the fact that international financial institutions and orthodox economists suggest that the "deeper causes" of the recent Asian crisis were not the observed macroeconomic disequilibria but rather structural, linked to the normal Asian way of doing business. Apart from crony capitalism and close relationships between firms, banks and governments, such analyses single out for particular attention the allegedly poor competitive environment in the crisis-affected countries (Thailand, Indonesia and the Republic of Korea). Further, in order to forestall future crises, it is argued that emerging markets need to be more open, transparent and "competitive". ${ }^{5}$

Nevertheless, it will be emphasized here that apart from these international dimensions, competition and competition policy are also important for developing countries in their own right. The present paper builds on the author's previous work in this area (Singh and Dhumale, 1999; Singh 2001a, 2001b) and extends it in a number of directions including specifically the analysis of:

(i) the relationship between competition, competition policy and development at the national level;

(ii) the important implications of the recent new conceptual advances in the theory of industrial organization for competition policy in developed and developing countries;

(iii) the impact of market power exercised by industrial country firms on developing countries, including a more complete examination of the effects of the current cross-border international merger wave;

(iv) in addition, the paper puts forward a proposal for establishing an international competition authority to monitor anti-competitive behaviour by large multinationals, and discusses the desirability of such an authority, and what form it should take to address the concerns and particular needs of developing countries.

The paper is organized as follows. Section II will consider the current state of competition and national competition policies in emerging markets and examine the relationship between competition, competition policy and economic development. Section III argues that although developing countries may not have needed competition policies in the past, they do so now in the wake of liberalization and globalization and the structural changes that these have brought about both at the national level (privatization and deregulation) and at the international level (the gigantic international merger movement of the 1990s). Section IV will examine competition policy in the United States, the European Community and 
Japan in the light of new developments in economic theory and draw implications for developing countries. Sections III and IV are concerned, by and large, with national competition policies. Section V considers the desirability or otherwise of multilateral competition policy for developing countries. In that context it also examines a proposal for an international competition authority. Section VI concludes by summing up the main message of the paper.

\section{Competition and competition policy}

\section{A. Competition and competition policy in emerging markets}

\section{The state of competition in emerging markets}

What is the nature of competition in emerging markets and how intensive is it? Strange as it may seem, in the light of market-oriented reforms which many developing countries have been implementing over the last two decades, there are not many empirical studies on this topic.

There are a bare handful of comparative international studies for developing countries which provide data on variables such as three- or four-firm concentration ratios. Even this information tends to be somewhat dated. There also exist for a few countries more detailed studies usually in the standard structure-conduct-performance (SCP) paradigm.

In the absence of hard evidence, it is not surprising that there is considerable disagreement amongst economists speculating about the degree of competition in developing countries.

Laffont (1998) suggests that these countries exhibit segmented product markets, discretionary government regulations and considerable corruption and hence are not very competitive. As noted earlier, the advocates of the structuralist theory of the Asian financial crisis of 1997-1998 believe that the crisis-affected Asian countries, including the Republic of Korea, suffered from poor competitive environments that resulted in over-investment. Michael Porter (1990), on the other hand, suggests that the Republic of Korea chaebol (large conglomerates) display highly competitive behaviour, and in the areas where the Republic of Korea has been internationally successful, these companies have been subject to intense national and international competition.
Some apparent support for the lack of competition referred to above is provided by evidence on how relatively difficult it is to start a new business in emerging markets, due to complex government regulations and bureaucracy. ${ }^{6}$ There are also considerable barriers to exit in many developing countries. Further, there is evidence that many developing countries favour large firms at the expense of small firms in the provision of finance and other measures.

Data in table 1 on concentration ratios lend some support to the competition deficit thesis. The table indicates that concentration ratios in developing countries have been quite high relative to advanced countries. However, table 2, which reports the share of small enterprises in total employment, suggests the opposite, i.e. that there may be greater competition in developing than in advanced countries. The differences between the United States and the developing countries in table 2 are quite dramatic. Whereas small enterprises (accounting for less than 10 workers) account for about 4 per cent of total employment in the United States, in emerging countries the share is several orders of magnitude higher.

Table 1

\section{CONCENTRATION RATIOS IN EMERGING MARKETS}

\begin{tabular}{lc}
\hline Economy & Share \\
\hline & \\
& Three-firm \\
& concentration ratios \\
\cline { 2 - 2 } Japan, 1980 & 56 \\
Republic of Korea, 1981 & 62 \\
Taiwan Province of China, 1981 & 49 \\
& \\
& \\
& Four-firm \\
Argentina, 1984 & 43 \\
Brazil, 1980 & 51 \\
Chile, 1979 & 50 \\
India, 1984 & 46 \\
Indonesia, 1985 & 56 \\
Mexico, 1980 & 48 \\
Pakistan, 1985 & 68 \\
Turkey, 1976 & \\
United States, 1972 & \\
\hline
\end{tabular}

Source: World Bank (1993). 
Table 2

\section{DISTRIBUTION OF EMPLOYMENT SHARES FOR SMALL ENTERPRISES IN DEVELOPING COUNTRIES AND THE UNITED STATES}

\begin{tabular}{|c|c|c|c|}
\hline \multirow[b]{2}{*}{ Country } & \multicolumn{3}{|c|}{ Number of workers } \\
\hline & $1-4$ & & $5-9$ \\
\hline United States, 1992 & 1.3 & & 2.6 \\
\hline Mexico, 1993 & 13.8 & & 4.5 \\
\hline Indonesia, 1986 & 44.2 & & \\
\hline Republic of Korea, 1973 & 7.9 & & \\
\hline Republic of Korea, 1988 & & & 12 \\
\hline Taiwan Prov. of China, 1986 & & & 20 \\
\hline India, 1971 & & 42 & \\
\hline Republic of Tanzania, 1967 & & 56 & \\
\hline Ghana, 1970 & & 84 & \\
\hline Kenya, 1969 & & 49 & \\
\hline Sierra Leone, 1974 & & 90 & \\
\hline Indonesia, 1977 & & 77 & \\
\hline Zambia, 1985 & & 83 & \\
\hline Honduras, 1979 & & 68 & \\
\hline Thailand, 1978 & & 58 & \\
\hline Philippines, 1974 & & 66 & \\
\hline Nigeria, 1972 & & 59 & \\
\hline Jamaica, 1978 & & 35 & \\
\hline Colombia, 1973 & & 52 & \\
\hline Republic of Korea, 1975 & & 40 & \\
\hline
\end{tabular}

Source: Tybout (2000); as well as for original sources for each country.

The data in table 2 are subject to some important statistical biases, all of which would, if anything, understate the share of small firms in the economies of developing countries. ${ }^{7}$ In more general terms, what the data in tables 1 and 2 indicate is the dualistic structure of developing country economies: a large modern sector accounting for a big proportion of total output exists side by side with a very large traditional sector of small enterprises which contribute an almost equal proportion of the economy's output. Relative to advanced countries, the share of the small-scale sector in developing countries in terms of employment would be larger than in terms of output because of the bigger differences in capital intensity of the two sectors in these countries.

Thus, as far as the intensity of competition in the two groups of countries is concerned, tables 1 and 2 provide conflicting information. Moreover, these data bear only on the static measures of concentration which have acknowledged shortcomings as indicators of the intensity of competition. To obtain a more complete picture of the competition process, it is necessary to supplement these static measures by indicators of the dynamics of the competition process. Fortunately there now exist some studies on this subject, and it is also useful that they employ different methodologies to model the dynamics. First, there is research by Glen, Lee and Singh (2001) which examines the persistency of profits in seven emerging markets in the 1980s and the early 1990s. The authors use exactly the same methodology as that employed by "persistence of profitability studies" for advanced countries. The results of their time series estimates of persistence coefficients in emerging markets are reported in table 3 . For purposes of comparison, table 4 summarizes the results of similar studies for advanced countries. Surprisingly, the results indicate that developing countries have consistently lower persistency coefficients than those observed for advanced countries, indicating that on the normal interpretation of such results, developing countries are subject to no less, if not greater competition, than advanced countries. The possible sources of bias in the empirical results for emerging economies have been examined by Glen, Lee and Singh (2002) and they find that these do not affect their main conclusions.

Complementary evidence to that of Glen, Lee and Singh is provided by another kind of research which also bears on the dynamics of the competition process but uses a different methodology. This research, which examines turnover, the entry and exit of firms, provides extremely interesting results. Some of the latter are summarized in table 5. The table

\section{Table 3}

\section{PERSISTENCE OF PROFITABILITY IN} EMERGING MARKETS

\begin{tabular}{lccc}
\hline & Mean $\lambda$ & Mean YLR & Mean $2^{2}$ \\
\hline Brazil & 0.013 & 0.003 & 0.418 \\
India & 0.229 & 0.003 & 0.282 \\
Jordan & 0.348 & 0.050 & 0.299 \\
Korea, Republic of & 0.323 & 0.005 & 0.300 \\
Malaysia & 0.349 & 0.009 & 0.302 \\
Mexico & 0.222 & -0.002 & 0.316 \\
Zimbabwe & 0.421 & 0.157 & 0.249 \\
\hline
\end{tabular}

Source: Glen, Lee and Singh (2001). 
Table 4

PERSISTENCE OF PROFITABILITY STUDIES FOR INDUSTRIAL COUNTRIES

\begin{tabular}{lllcrc}
\hline \multirow{2}{*}{ Author } & \multicolumn{1}{c}{ Country } & $\begin{array}{c}\text { Sample } \\
\text { period }\end{array}$ & $\begin{array}{c}\text { Observations } \\
\text { perfirm }\end{array}$ & $\begin{array}{c}\text { Number } \\
\text { offirms }\end{array}$ & $\begin{array}{c}\text { Sample means } \\
\text { (lambda [i]) }\end{array}$ \\
\hline \multirow{2}{*}{ Geroski and Jacquemin (1988) } & United Kingdom & $1947-1977$ & 29 & 51 & 0.488 \\
& France & $1965-1982$ & 18 & 55 & 0.142 \\
& Germany & $1961-1981$ & 21 & 28 & 0.410 \\
Schwalbach et al. (1989) & Germany & $1961-1982$ & 22 & 299 & 0.485 \\
Mueller (1990) & United States & $1950-1972$ & 23 & 551 & 0.183 \\
Cubbin and Geroski (1990) & United Kingdom & $1948-1977$ & 30 & 243 & 0.482 \\
Khemani and Shapiro (1990) & Canada & $1964-1982$ & 19 & 129 & 0.425 \\
Odagiri and Yamawaki (1990) & Japan & $1964-1982$ & 19 & 376 & 0.465 \\
Schohl (1990) & Germany & $1961-1981$ & 21 & 283 & 0.509 \\
Waring (1996) ${ }^{a}$ & United States & $1970-1989$ & 20 & 12,986 & 0.540 \\
\hline
\end{tabular}

Source: Goddard and Wilson (1999).

a Estimate based on pooled data for 128 industry groups. The mean lambda has been estimated by the present authors from the data in table 3 of Waring (1996).

Table 5

PLANT AND JOB TURNOVER IN DEVELOPING VERSUS DEVELOPED COUNTRIES ${ }^{a}$

\begin{tabular}{|c|c|c|c|c|c|c|c|c|}
\hline \multirow[b]{3}{*}{ Country (period covered) } & \multicolumn{4}{|c|}{ Turnover rates } & \multicolumn{3}{|c|}{ Market shares of entrants } & \multirow{3}{*}{$\begin{array}{l}\text { Minimum } \\
\text { plant } \\
\text { size } \\
\text { covered }^{b}\end{array}$} \\
\hline & \multicolumn{2}{|c|}{ Plants } & \multicolumn{2}{|c|}{ Jobs } & \multirow{2}{*}{$\begin{array}{c}<1 \\
\text { year old }\end{array}$} & \multirow{2}{*}{$\begin{array}{c}<5 \\
\text { year old }\end{array}$} & \multirow{2}{*}{$\begin{array}{c}<10 \\
\text { year old }\end{array}$} & \\
\hline & 1 year & 5 year & 1 year & 5 year & & & & \\
\hline Chile (1979-1986) & 8.5 & . & 26.9 & . & 3.6 & 15.3 & . & 10 \\
\hline Colombia (1977-1989) & 11.9 & . & 24.6 & . & 4.9 & 19.8 & & 10 \\
\hline Morocco (1984-1990) & 9.5 & . & 30.7 & . & 3.2 & . & . & 10 \\
\hline Republic of Korea (1983-1993) & . & 64.2 & . & . & . & 32.5 & . & 5 \\
\hline Taiwan Prov. of China (1981-1991) & . & 67.9 & . & . & . & 43.9 & 63.2 & $1^{c}$ \\
\hline United States (1963-1982) & . & $26.9^{d}$ & $18.9^{e}$ & 58.4 & . & $10.7^{d}$ & $18.6^{d}$ & 5 \\
\hline Canada (1973-1992) & . & . & 21.9 & . & . & . & . & 5 \\
\hline
\end{tabular}

Source: Tybout (2000), p. 26.

$a$ Let $\mathrm{N}_{t}$ be the number of plants observed in year $t$; $\mathrm{E}_{t}$ be the number of plants observed in year $t$ but not $t-1$; and $\mathrm{X}_{t}$ be the number of plants observed in year $t-l$ but not in year $t$. Then the entry rate is $\mathrm{E}_{t} / \mathrm{N}_{t-1}$ and the exit rate is $\mathrm{X}_{t} / \mathrm{N}_{t-1}$. The plant turnover rate is the average of these two statistics. Similarly, the rate of gross job creation is the number of jobs at entering plants plus the number of new jobs at expanding plants, divided by the initial number of jobs, and the gross job destruction rate is the number of jobs that disappear as plants contract or exit divided by the initial number of jobs. The sum of these two rates is the job turnover rate.

b Number of workers.

c The data set from Taiwan Province of China describes firms rather than plants.

$\boldsymbol{d}$ Figures are average rates of new entry rates across 4-digit industries.

$\boldsymbol{e}$ These figures are for 1973-1992. 
Table 6

NUMBER OF DEVELOPING COUNTRIES THAT HAVE ADOPTED COMPETITION LAWS, AS OF JUNE 2000

\begin{tabular}{|c|c|c|c|c|c|c|c|c|}
\hline Region & $\begin{array}{l}\text { Pre- } \\
1950 s\end{array}$ & $1950 s$ & $1960 s$ & $1970 s$ & $1980 s$ & $1990 s$ & $\begin{array}{c}\text { Under } \\
\text { preparation }\end{array}$ & Total \\
\hline Asia / Pacific & 0 & 0 & 2 & 2 & 2 & 14 & 6 & 26 \\
\hline Central / Eastern Europe & 0 & 0 & 0 & 0 & 1 & 16 & 1 & 18 \\
\hline Latin America and the Caribbean & 1 & 2 & 1 & 1 & 0 & 6 & 10 & 21 \\
\hline Africa & 0 & 1 & 0 & 1 & 2 & 14 & 10 & 28 \\
\hline Total & 1 & 3 & 3 & 4 & 5 & 50 & 27 & 93 \\
\hline
\end{tabular}

Source: Calculation based on table V.1 of UNCTAD (2002), p. 151.

indicates that there is greater turnover as well as entry and exit of firms in the small number of emerging markets for which such studies have been carried out than for advanced countries.

Apart from these two kinds of studies done on the dynamics of the competition process, there are also other types of evidence pertaining to the efficiency of emerging market industries and to scale economies which do not accord with the conventional anecdotal account of the lack of competition in emerging countries. This empirical research has recently been reviewed by Tybout (2000, p. 38) who sums up the situation as follows:

Indeed, although the issue remains open, the existing empirical literature does not support the notion that LDC manufacturers are relatively stagnant and inefficient. Turnover rates in plants and jobs are at least as high as those found in the OECD, and the amount of crossplant dispersion in measured productivity rates is not generally greater. Also, although smallscale production is relatively common in LDCs, there do not appear to be major potential gains from better exploitation of scale economies.

\section{The state of competition policy in developing countries}

Most developing countries have, until recently, operated without a formal competition policy. ${ }^{8}$ As table 6 suggests, until 1990 only 16 developing countries had a formal competition policy. With encouragement and technical assistance from inter- national financial institutions and the WTO, 50 countries have completed legislation for competition laws in the 1990s, and another 27 are in the process of doing so. It should, however, be borne in mind that it takes about 10 years for countries to acquire the necessary expertise and experience to implement such laws effectively (Scherer, 1994).

The main reason why developing countries did not have a formal competition policy was that it was not needed. This is because there was considerable state control over economic activity and if the government thought there was anti-competitive behaviour by some corporations or industries, it intervened directly and fixed prices such as for medicines and other essential products. Besides, state-owned industry was enjoined not to charge monopoly prices.

There is also evidence that competition laws have varied widely in countries where they have been introduced. Based on a survey of competition laws in fifty countries, World Bank (2002) reports that there are important inter-country differences in three dimensions: (a) the definition of dominance; (b) the treatment of cartels; and (c) enforcement. With respect to the definition of market dominance, for example, a majority of countries define it in qualitative terms. However, 22 countries out of 50 define it quantitatively, although with widely varying thresholds, as seen in table 7. Similarly, the treatment of cartels varies greatly in its severity. On the effective implementation of competition laws, the World Competitiveness Yearbook, 2000 estimates that based on a survey of top- and middle-management of firms in each country studied, competition authorities in ad- 


\section{Table 7}

\section{BENCHMARKS OF PRODUCT MARKET DOMINANCE IN COMPETITION LAWS AROUND THE WORLD}

(Per cent)

\begin{tabular}{lc}
\hline Country group & $\begin{array}{c}\text { Market share } \\
\text { of the firm }\end{array}$ \\
\hline \multicolumn{2}{l}{ Developing and transition countries } \\
East Asia & $50-75$ \\
Eastern Europe and Central Asia & $30-40$ \\
Africa & $20-45$ \\
Industrial countries & \\
United States & Two-thirds or more \\
European Union & $40-50$ \\
\hline
\end{tabular}

Source: World Bank (2002), p. 140.

vanced countries are 40 per cent more effective than their counterparts in developing countries. ${ }^{9}$

\section{B. Competition, competition policy and economic development}

\section{Competition and competition policy}

There would appear to be no obvious relationship between competition policy and competition since, as we have seen, many developing countries have been able to maintain considerable competition in product markets despite the absence of a formal competition policy. An analytical reason for this lack of correspondence between competition and competition policy lies in the fact that developing country firms have been increasingly subject to foreign competition with the liberalization of their economies. In the Asian NICs, even while they maintained selective import controls, their export-oriented policies exposed firms to competition in foreign markets. An additional reason was that governments in these countries organized contest-based competitions for state subsidies which were conditioned on the achievement of certain performance standards (export targets, foreign exchange earnings, and technological upgrading are a few of the contest objectives utilized by governments), with the winners receiving greater aid from the government. ${ }^{10}$

\section{Competition and economic development}

The relationship between competition and economic development is controversial, both in economic theory and in relation to empirical evidence. Economic orthodoxy posits a monotonic positive relationship between the two variables and therefore suggests that the greater the intensity of competition the better the economic performance. ${ }^{11}$ However, modern economic analysis seriously qualifies that conclusion. As Telser (1987) observed, despite the reluctance of "many economists to accept the proposition that competition may be excessive because the received theory regards competition as always good, the more there is the better", new developments in the theory of industrial organization indicate that the excess competition proposition is valid. These developments suggest that maximum competition is not necessarily the optimal degree of competition for promoting either economic welfare in the static sense, or, more importantly, in the dynamic sense, maximizing the long-term trend-rate of growth of productivity in the economy. ${ }^{12}$

In the real world, it is recognized that the case for competition necessarily spurring economic efficiency at the microeconomic level is very weak because of the separation of management and control in large corporations, asymmetric information, transactions costs and agency problems. Indeed, Nickell (1996) suggests that the case for a positive link between competition and increased effort by economic agents is both theoretically tenuous and has little empirical support. ${ }^{13}$ Nickell argues, therefore, that the virtues of competition are more convincing at the broad-brush impressionistic level rather than on the basis of rigorous econometric studies. He cites the broad, long-term experience of Japan (good - due to a high level of competition) and that of communist Eastern Europe (bad - because of lack of competition) as the best confirmation of the positive relationship between competition and economic development.

The seminal World Bank (1991) Report which provided the intellectual basis for the Washington Consensus contended on its first page that:

Competitive markets are the best way yet found for efficiently organizing the production and distribution of goods and services. Domestic and external competition provides the incentives that unleash entrepreneurship and technological progress. 
The Report's basic analytical approach was to suggest that the fastest growing countries were those with the most rapid growth of total factor productivity (TFP). The latter in turn depended on domestic and foreign competition achieved through free markets. The role of the state was, in this view, essentially that of a "night watchman" concerned with providing human capital and physical and social infrastructure that provides a conducive environment in which business can flourish. This may be a plausible model in theory but in practice it did not describe the East Asian experience at all accurately. However, as World Bank (1993) itself acknowledged in its subsequent report on the East Asian miracle, these countries did not have maximum competition in product, capital or labour markets, but rather strived to achieve an optimal degree of co-operation and competition. Thus, for example, Japan and the Republic of Korea implemented selective import controls; fostered close relationships between government, business and finance; and discouraged foreign investment while importing technology from abroad by other means. ${ }^{14}$ The "broad-brush" East Asian evidence, in short, does not bear out Nickell's claims for the virtues of competition in relation to economic development. The experience of China, which for the last two decades has had one of the fastest growth rates in the world, is also consistent with this East Asian story. The Chinese economy has been able to register such fast growth rates despite its segmented product markets and highly imperfect capital and labour markets.

Nickell's (1996) own study reports a positive relationship between competition and long-run productivity growth for firms in the United Kingdom. He notes, however, that in general empirical evidence for the claim that competition enhances corporate performance is not overwhelming. Detailed microeconomic research also indicates that there is no monotonic relationship between competition (as proxied by the number of firms) and managerial effort or other benefits of competition. On the basis of game-theoretical models as well as empirical studies, World Bank (2002, p. 134) notes that it is possible to attain the benefits of competition - greater efficiency and innovation in product markets - with "some" degree of competition, but competition by a large number of firms is not always required.

Another useful piece of evidence comes from an interesting recent study by Aw, Chung and Roberts (2002) that systematically compares turnover and exit and entry rates for the Republic of Korea and Taiwan Province of China firms in seven compara- ble industries in the late 1980s. The results indicate that, on all the dynamic measures of competition examined by the authors, Taiwan Province of China was more competitive than the Republic of Korea. Nevertheless, it is worth noting that the overall trend rates of growth in the two economies have been very similar in the period examined as well as over a longer period.

To sum up, the main point that emerges from the above discussion of the relationship between competition and economic development is that a suitable combination of co-operation and competition is more likely to enhance societal welfare than competition alone. This conclusion is supported not only by the experience of the East Asia countries and China, but also by that of industrial districts in Italy and in many other countries. ${ }^{15}$ Further, recent theoretical developments suggest that, in relation to innovation, "inter-firm co-ordination even among horizontal competitors can bring substantial welfare benefits." (Baumol, 2001 p. 736).

\section{Competition policy, liberalization and globalization}

\section{A. Competition policy, privatization and deregulation}

Notwithstanding developing countries' lack of experience with competition policies, and the general scepticism about whether maximum or perfect competition is optimal for long-term productivity growth, there are good reasons to suggest that, under the present global economic arrangements, it is important for developing countries to establish formal competition policies. This is primarily because enormous structural changes which have occurred in developing country economies during the last two decades as a result of privatization and deregulation. These have been spawned by technological, economic, political and ideological forces which are leading to liberalization as well as greater integration of the world economy. As many of the privatized firms include natural monopolies, it is important that an appropriate regulatory and competition policy framework be in place to ensure improved economic performance. In relation to the question of perfect versus optimum degree of competition, it will be appreciated that nuanced competition laws will be required to implement optimal competition. 
A significant danger is that privatization may simply lead to a substitution of public sector monopolies by private monopolies, which would arguably reduce social welfare, as unlike in the case of the public sector, the private sector is usually under no formal injunction to advance people's well being. In addition, the experience of privatization in the United Kingdom and many other countries suggests that it is not ownership itself which affects performance, but rather the external environment, particularly as regards to competition which is the more important factor. ${ }^{16}$ Hence, the need for an appropriate competition policy.

\section{B. The international merger wave and competition policy in developing countries}

Another extremely important reason for developing countries to have competition laws today derives from the huge international cross-border merger movement which has been re-shaping the world economy during the last decade. UNCTAD $(2000,2001)$ data shows that the global value of cross-border acquisitions has risen from about 0.5 per cent of world GDP in the mid-1980s to well over 2 per cent in 2000 . As these international mergers, as well as those between large corporations within the developed countries themselves, are quite central to the policy proposals which will be put forward later, it is important to carefully review the stylized facts and what the vast literature on mergers has taught us about these phenomena.

\section{The 1990s global merger wave in historical perspective}

The first stylized fact about mergers is that these normally come in waves. Second, analyses suggest that each wave generally has the stamp of special factors; these normally lead to differing perceptions concerning asset values among economic agents which in turn encourages mergers (Gort, 1969). Among the largest recorded waves in the United States is that between about 1890 and $1905 .{ }^{17}$ This wave - dominated by "mergers for monopoly" - saw the creation of giant United States firms which subsequently dominated the industrial landscape for much of the $20^{\text {th }}$ century. Ironically, it is thought that the Sherman Antitrust Act of 1890, by outlawing co-operation between firms, thereby encouraged mergers. ${ }^{18}$ The 1920 s wave was labelled by Stigler as "mergers for oligopoly". The wave of the 1960s was characterized by conglomerate mergers and that of the 1980s by the "bust-up" of the same conglomerate mergers and by leveraged buy-outs.

The 1990s merger movement, in contrast, has witnessed "size-increasing blow-up mergers" creating very large global players. This wave had its origin in new technology, globalization and deregulation, factors which not surprisingly lead to dramatic disturbances in economic agents' perceptions of market valuations of firms, fuelling mergers. Many of these mergers are defensive in that, once one large player takes over another company, other players are obliged to follow suit, through defensive takeovers, in order to maintain their market share. Holmstrom and Kaplan (2001) argue that a distinguishing feature of the 1990s merger wave in the United States were enormous changes in corporate governance. In their view, during the 1980s the capital market exercised an increasing influence on corporate performance through leveraged buy-outs and other hostile tender offers for firms. However, by the 1990s managers appear to have internalized the virtues of maximizing shareholder value as their main motivation, not least because they themselves benefited through stock options. In brief, the work of leading scholars in this area suggests that the 1990s takeover wave in the United States and in the world economy has been motivated by firms trying to achieve domination and bigger size in a global market. This has been effected by offensive takeovers in the market for corporate control, even though their intent in terms of product market competition may have been defensive, e.g. maintaining market share in the face of takeovers by competing firms.

The United States merger wave of 1990s appears to come to an end with the deflation of technology bubble on the stock market in the first half of 2000. However, once the stock market revives, there continue to exist a number of factors which would propel another merger movement. In previous merger waves most mergers were national, that is, within national boundaries. This was particularly striking in the merger wave of the 1960s which took place simultaneously in most leading industrial economies. However, despite these waves occurring at the same time in many countries, there were surprisingly few cross-border takeovers (Singh, 1992). In that sense, the 1990s merger wave, with a huge component of cross-border takeovers, has been quite unique.

It is also important to note that most crossborder mergers take place among industrial countries 


\section{Table 8}

\section{CROSS-BORDER M\&As: ${ }^{a}$ SALES AND PURCHASES, 1998-1999}

(US\$ billions)

\begin{tabular}{|c|c|c|c|c|}
\hline \multirow[b]{2}{*}{ Region/economy } & \multicolumn{2}{|c|}{ Sales } & \multicolumn{2}{|c|}{ Purchases } \\
\hline & 1998 & 1999 & 1998 & 1999 \\
\hline Developed countries & 445.1 & 644.6 & 511.4 & 677.3 \\
\hline European Union & 187.9 & 344.5 & 284.4 & 497.7 \\
\hline United States & 209.5 & 233.0 & 137.4 & 112.4 \\
\hline Japan & 4.0 & 15.9 & 1.3 & 9.8 \\
\hline Developing countries & 80.7 & 63.4 & 19.2 & 41.2 \\
\hline Africa & 0.7 & 0.6 & 0.2 & 0.4 \\
\hline Latin America and the Caribbean & 63.9 & 37.2 & 12.6 & 24.9 \\
\hline Europe & & 0.3 & & . \\
\hline Asia & 16.1 & 25.3 & 6.4 & 15.9 \\
\hline Pacific & . & 0.1 & . & . \\
\hline Central and Eastern Europe ${ }^{b}$ & 5.1 & 10.3 & 1.0 & 1.6 \\
\hline World $^{c}$ & 531.6 & 720.1 & 531.6 & 720.1 \\
\hline
\end{tabular}

Source: UNCTAD (2000).

a Cross-border M\&As that result in the acquisition of more than 10 per cent equity share.

$b$ Includes the countries of the former Yugoslavia.

c Includes amounts which cannot be allocated by region.

themselves. They are closely linked with foreign direct investment (FDI). Indeed, most of the FDI among advanced countries nowadays occurs through this channel. However, the incidence of cross-border takeovers via FDI is much lower in developing than in advanced countries. The overall estimate of the size of cross-border takeovers in developing countries (table 8) is somewhat misleading as it is heavily influenced by China. The latter is the largest developing country recipient of FDI, but it generally permits only greenfield FDI. If China is excluded, cross-border takeovers constitute a far larger and growing part of FDI in other developing economies (UNCTAD, 1999).

\section{Benefits and costs of mergers}

What are likely to be the benefits and costs of the 1990s merger wave to different groups of countries and to the global economy? In theory, takeovers can increase societal welfare through two separate channels. The first is the threat of takeovers, which may oblige inefficient firms to become more efficient; the second is through the takeovers themselves which may lead to synergies between the activities of the acquired and acquiring firms. An obvious social cost of the second channel is the potential monopoly power of the merged firms.

It is significant that, although takeovers and mergers are central to the theory of the firm, to industrial organization, privatization and deregulation amongst other fields of study, there is no unified theory of mergers as such (see further Singh, 1992). However, issues concerning the costs and benefits of mergers have been explored in a vast literature comprising both analytical and empirical studies. ${ }^{19}$ In order to give coherence to the empirical studies, I shall briefly review the work on the nature of the takeover selection mechanism on the stock market, this includes, inter alia, the question above concerning the extent to which the threat of takeovers is effective in improving economic performance of in- 
Table 9

\section{MERGER STUDIES RESULTS: A SUMMARY}

\section{Characteristics}

Size

Profitability

Growth

Market-to-book ratio

\section{Effects of the acquisition}

Return on share

Profits

Sales

Market share

Investment

$\mathrm{R} \& \mathrm{D}$

Asset restructuring

Management turnover

Labour costs

\section{Elements of success}

Relatedness

Size difference

Motive

Market-to-book ratio

Financing

\section{Bidder}

$>$ industry, $>$ target

$>$ industry, $>$ target

$>$ industry, $>$ target

$<$ industry

announcement about equal to long-run losses

down

down

down, in most cases at the loss of the target

about same

about same

yes

yes

down

\section{Target \\ $<$ industry, < bidder \\ $>$ industry, $<$ bidder \\ $<$ industry, $<$ bidder \\ ?}

premium 20-50 per cent

related business $>$ horizontal $>$ vertical $>$ conglomerate

big difference $>$ equal size

tender offer $>$ merger; hostile ? friendly ?

value bidders $>$ glamour bidders

cash > stock

Source: Tichy (2001).

efficient firms (measured by profitability). Singh (1971, 1975), which were among the first studies on this subject, investigated this by comparing the multivariate characteristics of (a) acquired and nonacquired firms; (b) acquiring and acquired firms; and (c) acquiring and non-acquiring firms. Briefly, Singh's main result was that selection in the market for corporate control does not occur solely on the basis of performance (e.g. profitability or stock market valuation); it also occurs on the basis of size which is the more important discriminator. Thus, a large unprofitable firm has a better chance of survival than a small, relatively more profitable firm. These results on the empirical characterization of the selection mechanism have been confirmed in many subsequent studies (see table 9 which summarizes a wide range of studies from different countries on this and other points related to takeovers).

The effects of mergers have been studied by industrial organization economists in terms of profitability and by financial economists in terms of stock market valuation. Most studies by industrial organization economists invariably find reduced profitability after mergers, or, at the best, no change, after controlling for all the relevant factors. ${ }^{20}$ Financial economists, on the other hand, believe that mergers increase the stock market value of the combined firms. This valuation undoubtedly increases during a short period of a few weeks preceding the takeover event. At that time, the acquired firm's value increases by an average of 20-30 per cent; the acquiring firm's value remains more or less the same. The combined result is greater value. However, the acquiring firm's shareholders suffer systematic losses which begin as soon as six months after the takeover and which may go on for a number of years.

On the question of whether mergers lead to concentration or monopoly power, there is a large and controversial literature. On one side are economists who believe that with liberalization of trade throughout the world the size of the relevant market has enormously increased and therefore the mo- 
nopoly power effects of mergers are no longer significant. This view is strongly contested by others. Tichy (2001), in his comprehensive survey of the merger literature, notes that:

Contrary to widely held opinion, concentration is a quickly increasing problem, even with the extension of markets resulting from the new policy of the big corporations. Driven by the superficial advice of their consultants they strive hard to belong to the top three in their respective market, and sometimes they concentrate forcefully on narrowly limited markets to achieve this goal. If they are successful, a great number of oligopolistic markets with very few competitors result, strongly supporting collusion. (Tichy, 2001, p. 20)

He concludes by observing that the "goal of being among the three leading players in the world market creates oligopolistic power if the competitive fringe is not extremely strong, as the likelihood of strong competition with fewer than four to five competitors is rather small."

It will be useful at this point to review a recent massive study of the effects of mergers carried out by Gugler et al. (2001). They examined mergers of the decades of the 1980s and the 1990s in a large number of countries in all parts of the world, where the relevant data is available. Defining merger as a transaction where more than 50 per cent of the equity of the "victim" firm is acquired, their data suggests that between 1981 and 1998 there were nearly 70,000 merger announcements, of these 45,000 were actually completed, nearly half of them in the United States (see table 10). The results of their study of the effects of these mergers on profits, sales and market value and their overall findings are reported in table 11 . These results are broadly consistent with those of much of the merger literature. The effects of mergers on profitability are positive but insignificant, until the fifth year after merger when the positive effect is significant only at the 10 per cent level. The impact on sales and market value are strongly negative and statistically significant from the merger year onwards.

In terms of the methodology presented by Gugler et al., mergers which enhance the efficiency of the merging firms should demonstrate an increase in both their profits and their sales. An efficiencyreducing merger would have a negative effect both on sales and on profits. A merger which increases market power would increase profits and reduce sales. Overall, the authors' results indicate that no more than a quarter of the mergers appear to increase efficiency, and a quarter increase profits by increasing the market power of the firms involved. About 50 per cent of the mergers fail, paying for increased sales by reduced profits or losing sales as well as profits. The authors of this study were also able to compare the effects of cross-border mergers with those of domestic ones. The results suggest broadly similar effects.

The above analysis of the effects of mergers has taken a rather narrow, economic efficiency view of their benefits and costs. A more comprehensive analysis must also include a discussion of the distributional consequences of mergers as these often tend to be quite large. The benefits of mergers may, for example, go to shareholders whilst the costs may be borne by workers who lose their jobs as a result of rationalization. Although the importance of these distributional issues is recognized (see for example Shleifer and Summers, 1988; Singh, 1993), there is very little empirical literature on the subject. In the context of the present paper the issue of the distribution of the gains and costs of mergers between countries is also pertinent.

\section{The international merger movement and developing countries}

The foregoing examination of the causes and effects of the current international merger movement raises important concerns for developing countries. First, there are the obvious questions of increased market power of large multinationals and their potential abuse of dominance. Developing countries are clearly affected directly by the monopoly power effects of international mergers when a foreign multinational acquires a domestic firm. However, they are also affected indirectly even when mergers take place outside their jurisdictions, e.g. within advanced countries themselves. The "rule of being in the top three", as Tichy argues, reduces the contestability of markets and is especially harmful to the interests of late industrialising countries whose firms are building up their capabilities to compete in international markets. The reduced contestability of markets is therefore of special concern for developing countries.

Developing countries clearly need a competition policy in order to be able to deal with these issues of market dominance and abuse of dominant positions. However, even with such legislation on the statute books these countries may not have the power 


\section{CROSS-BORDER DEALS, HORIZONTAL AND CONGLOMERATE MERGERS} BY COUNTRY GROUPINGS

(Percentage unless otherwise indicated)

\begin{tabular}{|c|c|c|c|c|c|c|}
\hline & Until 1990 & 1991/92 & 1993/94 & 1995/96 & $1997 / 98$ & Total \\
\hline \multicolumn{7}{|l|}{ United States } \\
\hline Number of deals & 8194 & 1965 & 2840 & 3783 & 4369 & 21151 \\
\hline Value of deals (US\$ million) & 242.44 & 104.45 & 139.33 & 195.70 & 313.94 & 221.19 \\
\hline Cross-border deals & 0.03 & 0.12 & 0.14 & 0.16 & 0.17 & 0.11 \\
\hline Horizontal mergers & 0.38 & 0.47 & 0.49 & 0.49 & 0.48 & 0.44 \\
\hline Conglomerate mergers & 0.56 & 0.48 & 0.47 & 0.48 & 0.49 & 0.51 \\
\hline \multicolumn{7}{|l|}{ United Kingdom } \\
\hline Number of deals & 1180 & 501 & 790 & 1138 & 1148 & 4757 \\
\hline Value of deals (US\$ million) & 220.07 & 113.82 & 61.11 & 97.31 & 158.92 & 139.32 \\
\hline Cross-border deals & 0.35 & 0.30 & 0.27 & 0.27 & 0.36 & 0.32 \\
\hline Horizontal mergers & 0.31 & 0.36 & 0.35 & 0.38 & 0.36 & 0.35 \\
\hline Conglomerate mergers & 0.64 & 0.59 & 0.62 & 0.58 & 0.61 & 0.61 \\
\hline \multicolumn{7}{|l|}{ Western Europe } \\
\hline Number of deals & 986 & 2125 & 1996 & 2364 & 2059 & 9530 \\
\hline Value of deals (US\$ million) & 398.95 & 188.63 & 163.41 & 144.44 & 320.33 & 241.90 \\
\hline Cross-border deals & 0.54 & 0.24 & 0.27 & 0.33 & 0.48 & 0.35 \\
\hline Horizontal mergers & 0.37 & 0.44 & 0.37 & 0.36 & 0.34 & 0.38 \\
\hline Conglomerate mergers & 0.59 & 0.53 & 0.59 & 0.61 & 0.63 & 0.59 \\
\hline \multicolumn{7}{|l|}{ Japan } \\
\hline Number of deals & 172 & 88 & 61 & 151 & 168 & 640 \\
\hline Value of deals (US\$ million) & 528.91 & 474.11 & 198.55 & 754.97 & 177.43 & 478.73 \\
\hline Cross-border deals & 0.81 & 0.72 & 0.59 & 0.34 & 0.45 & 0.57 \\
\hline Horizontal mergers & 0.33 & 0.30 & 0.36 & 0.35 & 0.35 & 0.34 \\
\hline Conglomerate mergers & 0.62 & 0.70 & 0.61 & 0.63 & 0.61 & 0.63 \\
\hline \multicolumn{7}{|c|}{ Australia, New Zealand, Canada } \\
\hline Number of deals & 671 & 425 & 549 & 767 & 875 & 3287 \\
\hline Value of deals (US\$ million) & 357.63 & 69.55 & 61.56 & 126.97 & 109.70 & 150.54 \\
\hline Cross-border deals & 0.38 & 0.23 & 0.32 & 0.28 & 0.36 & 0.32 \\
\hline Horizontal mergers & 0.44 & 0.43 & 0.48 & 0.40 & 0.39 & 0.42 \\
\hline Conglomerate mergers & 0.52 & 0.55 & 0.49 & 0.57 & 0.58 & 0.54 \\
\hline \multicolumn{7}{|l|}{ Rest of world } \\
\hline Number of deals & 371 & 553 & 831 & 1731 & 1733 & 5219 \\
\hline Value of deals (US\$ million) & 278.88 & 150.74 & 88.64 & 112.76 & 142.92 & 132.60 \\
\hline Cross-border deals & 0.50 & 0.26 & 0.33 & 0.25 & 0.35 & 0.31 \\
\hline Horizontal mergers & 0.34 & 0.36 & 0.35 & 0.37 & 0.37 & 0.36 \\
\hline Conglomerate mergers & 0.59 & 0.59 & 0.63 & 0.60 & 0.60 & 0.60 \\
\hline \multicolumn{7}{|l|}{ Total } \\
\hline Number of deals & 11574 & 5657 & 7067 & 9934 & 10352 & 44584 \\
\hline Value of deals (US\$ million) & 260.63 & 131.11 & 116.51 & 162.70 & 243.09 & 199.71 \\
\hline Cross-border deals & 0.16 & 0.21 & 0.23 & 0.24 & 0.30 & 0.23 \\
\hline Horizontal mergers & 0.37 & 0.43 & 0.42 & 0.42 & 0.41 & 0.41 \\
\hline Conglomerate mergers & 0.57 & 0.53 & 0.54 & 0.55 & 0.56 & 0.55 \\
\hline
\end{tabular}

Source: Gugler et al., p. 27. 


\section{Table 11}

EFFECTS OF MERGERS FOR FULL SAMPLE

\begin{tabular}{|c|c|c|c|c|c|c|c|c|c|c|c|c|}
\hline \multirow{2}{*}{$\begin{array}{l}\text { Years } \\
\text { after } \\
\text { the } \\
\text { merger }\end{array}$} & \multicolumn{4}{|c|}{ Profitability } & \multicolumn{4}{|c|}{ Sales } & \multicolumn{4}{|c|}{ Market value } \\
\hline & $\begin{array}{l}\text { Differ- } \\
\text { ence }^{a}\end{array}$ & $p$-value & Obs. & Pos. & $\begin{array}{l}\text { Differ- } \\
\text { ence }^{a}\end{array}$ & $p$-value & Obs. & Pos. & $\begin{array}{l}\text { Differ- } \\
\text { ence }^{a}\end{array}$ & $p$-value & Obs. & Pos. \\
\hline 0 & . & & & . & & . & . & . & 50.512 & 0.000 & 6211 & 0.524 \\
\hline 1 & 1.884 & 0.580 & 2603 & 0.554 & 73.654 & 0.008 & 2603 & 0.688 & -49.262 & 0.035 & 5282 & 0.472 \\
\hline 2 & 3.864 & 0.413 & 2171 & 0.556 & -87.435 & 0.025 & 2171 & 0.652 & -177.464 & 0.000 & 4189 & 0.437 \\
\hline 3 & 5.081 & 0.395 & 1810 & 0.536 & -193.993 & 0.000 & 1810 & 0.621 & -342.415 & 0.000 & 3416 & 0.401 \\
\hline 4 & 11.660 & 0.119 & 1474 & 0.566 & -189.038 & 0.008 & 1474 & 0.610 & -528.251 & 0.000 & 2784 & 0.375 \\
\hline 5 & 15.989 & 0.097 & 1210 & 0.565 & -263.392 & 0.004 & 1210 & 0.588 & -865.520 & 0.000 & 2218 & 0.357 \\
\hline
\end{tabular}

Source: Gugler et al., p. 29.

a In million US dollars.

to restrain cartels and other uncompetitive conduct by large multinationals, owing to inadequate development of the legal and institutional framework, lack of information and difficulties of proving that prices an being manipulated by international cartels. It has become conventional to underplay the practical significance of cartels presumably on the ground that these arrangements tend to be short lived and their incidence is quite low. However, the United States anti-trust authorities, which have long held a strong anti-cartel position, made their stance even stronger in the early 1990s. By the end of the decade the United States position was accepted by European Union and other advanced countries. Consequently, several industrial countries have passed legislation to stiffen the penalties for participation in illegal cartels. It is also increasingly recognized that the illegal cartels that are actually detected and prosecuted are merely the tip of a large iceberg. ${ }^{21}$ Recently, the United States government fined participants in a European vitamin's cartel a record sum of $\$ 750$ million. If such cartels can operate in an economy like that of the Unite States, with its long history of antitrust laws and their enforcement, it is more than likely that their incidence will be quiet high in developing countries.

The experience of the 1930s with widespread cartelization in peripheral countries points in the same direction. During that decade, it is estimated that very roughly 30 to 50 per cent of the world's exports were subject to cartel manipulation of prices. The post-World War II reduction in the incidence of cartelization may mainly be attributed to two factors: (a) stricter enforcement of laws against cartels in advanced countries, particularly the United States; (b) the replacement of cartels by straight forward mergers between firms. ${ }^{22}$ However, more recently, the European Union Competition Commission has begun to vigorously prosecute cartel arrangements in many different industries, so as to ensure that a single European market is not thwarted by cartelization and division of markets. ${ }^{23}$ The latter was wide spread in the 1930s in the so-called sphere of influence cartelization. The latter often took the form of European companies, for example, withdrawing from competition with the United States firms in Latin American countries as these lay in the American sphere of influence. In return, the United States corporations would undertake not to compete with Europeans in Southern and Eastern Europe, recognizing these countries to be in the European sphere of influence.

It is important to note that the anti-cartel legislation in advanced countries does not normally extend to developing countries. Indeed, on the contrary, exports or foreign markets are often explicitly exempted from such laws. In these circumstances, in addition to domestic competition policies, developing countries clearly require considerable co-operation from advanced countries to be able to cope at all effectively with anti-competitive behaviour of advanced country cartels between the large multinationals. From the perspective of poor countries, it is therefore necessary not only to have the 
right kind of domestic competition policies, but also an appropriate framework for international co-operation on competition issues.

\section{Competition policy and developing countries: taking account of the developmental dimension}

What kind of competition policy would be suitable for developing countries? In the light of the previous discussion, such a policy must at least be able to (a) restrain anti-competitive behaviour by domestic privatized large firms; (b) limit abuses of monopoly power by mega-corporations created by the international merger movement; and (c) promote development.

The question of what constitutes an appropriate competition policy for late industrializing economies will be examined here on the basis of economic theory and the historical experience of the developed countries - the European Union countries, the United States and Japan.

\section{A. Competition policy and development: analytical considerations}

Important guidance for competition policy is offered by the economic theory of the "second best". Laffont puts forward the basic argument on the second best in the following terms:

Competition is an unambiguously good thing in the first-best world of economists. That world assumes large numbers of participants in all markets, no public goods, no externalities, no information asymmetries, no natural monopolies, complete markets, fully rational economic agents, a benevolent court system to enforce contracts, and a benevolent government providing lump sum transfers to achieve any desirable redistribution. Because developing countries are so far from this ideal world, it is not always the case that competition should be encouraged in these countries. (Laffont, 1998, p. 237)

The basic idea is, of course, that, if some of the conditions for a competitive equilibrium are violated, a second-best solution would involve restrictions on competition. Precisely what those restrictions should be is a much more difficult question, because that depends on the nature and structure of the existing distortions and whether these can be remedied through other means. Laffont is quite pessimistic about developing countries being able to implement competition laws because of widespread rent-seeking, corruption and ineffective governments in these countries. He makes a valid point that implementation of competition law requires a strong state which many developing countries lack.

Pessimism is not, however, warranted in the case of all developing countries. Many semi-industrial countries have strong and effective governments, though not always fully democratic. These include some of the most populous countries in the developing world, such as China, India, Brazil and Mexico. There are also several well-known developmental states. Moreover, the question of corruption should be kept in perspective. Many of the East Asian countries, including China, do not rank very high in the transparency league table, and yet, these are the countries with the fastest rates of sustained growth in the history of humankind. Indonesia, for example, has become a byword for corruption during Suharto's regime, yet during his thirty-year rule the country's record was the best in the world in reducing poverty (Stiglitz, 1998)..$^{24}$ In the Republic of Korea, the two presidents who presided over that country's rapid industrial expansion in the late 1970s and 1980s were each convicted by courts for accepting hundreds of millions of United States dollars in bribes. Even in relation to developed countries, the post-World War II Italian economic miracle does not seem to have been hampered by widespread cronyism and corruption within the political establishment. There is clearly no simple relationship between corruption, economic growth and a country's ability to implement interventionist economic and industrial policy including competition policy.

What kind of competition policy would be appropriate for those developing countries with reasonably effective states as well as the necessary institutional framework to carry out a developmental program? The central point here is that the second-best framework outlined above is much too narrow for taking into account the developmental dimension. This is in part because for a developing country the purpose of competition policy cannot simply be the promotion of competition as a good thing per se, but to foster economic development. This would in some instances involve restriction of competition and in others its vigorous promotion. In order to raise the living standards of their people over time, developing countries need high rates of 
investment to achieve fast growth of productivity. High rates of investment in turn normally require reasonable, if not high, rates of profits in order to maintain the private sector's propensity to invest. This consideration leads to the view that there that there may at times be too much competition rather than too little. Competition would be too much if it leads to price wars, sharp falls in profits, all of which are likely to diminish the corporate desire to invest. In the real world of incomplete and missing markets which is particularly the case in developing countries, the latter may also require government co-ordination of investment decisions to prevent over-capacity. A developing country cannot therefore afford to have maximum competition, rather it must operate with an optimal degree of competition or with an appropriate blend of competition and cooperation to achieve its long term goals of faster and sustained economic growth. As was noted earlier in the discussion in Section III, this is also the conclusion that emerges from new developments in the theory of industrial organization.

To sum up, the above analysis suggests that competition policy cannot be a unique, one-size-fitsall, policy which is appropriate for all developing countries. The optimal policy will differ between countries depending on their stage of development and the effectiveness of their governments as well as the supporting institutional framework.

\section{B. Competition policies in advanced countries}

It may be useful to consider briefly what the nature and practice of competition policy has been in developed countries. What lessons can developing countries draw from their experience?

\section{United States}

The United States is the country with the longest history of anti-trust laws and laws prohibiting restraints on competition. In the period from the end of World War II to the 1980s, with respect to the former, the United States followed a structural policy which more or less forbade mergers in the same industry. This is thought by some to have encouraged the conglomerate mergers of the 1960s. With the liberalization of the world economy and the United States' difficulties in maintaining equilibrium in its current account, there appears to have been a relaxation of the strict interpretation of the competition laws. It is a moot point whether this was due more to the influence of foreign competition or to that of the Chicago School, but the upshot was that the enforcement of competition laws became relatively relaxed. For example, the Federal Trade Commission began to take account of economies of scale as a defence against charges of increased market power. More recently, there have been further relaxations of anti-trust laws in the light of advances in economic theory and the courts' acceptance of these. In a recent review, Baker (1999) concluded as follows:

Three decades ago, antitrust law relied heavily upon "per se" rules, which took the broadbrush approach of deeming certain classes of business practices anticompetitive without regard to their effects in any particular case. Today, a case-by-case analysis is more common, often under the judicial rubric of applying the "rule of reason". (Baker, 1999, p. 191)

The per se rules which prevailed for a long time in the United States conception and implementation of anti-trust law reflected the belief that competition is a good thing per se, without regard to its economic consequences. This is the doctrine that is now changing.

\section{European Union}

The European Union's competition law consists of Article 81 and 82 of the Treaty of Rome and the national competition laws of the member states. The primary objective of these laws is the creation of the single European market. However, European competition law also makes provision for industrial policy under strict guidelines as well as provision for other objectives such as fairness, equality of income distribution and other social goals (e.g. reducing regional disparities and unemployment).

Audretsch, Baumol and Burke (2001) note two shortcomings in European Union competition law from the perspective of dynamic efficiency: the lack of clarity on the social welfare objective of the laws and an emphasis on static efficiency. They argue that the economic prescription for competition policy is relatively simple only if one ignores such phenomena as (a) the variation in the abilities of firms to exploit particular profit opportunities; (b) the evolution of such capability with the passage of time; or (c) the manipulation of barriers to entry or the incentives for innovation and its possible abuse as a means to undermine competition. (Audretsch et al. 2001, p. 629) 


\section{JAPANESE CARTEL AGREEMENTS EXEMPTED FROM THE ANTI-MONOPOLY LAW BY THE FAIR TRADE COMMISSION OR THE COMPETENT MINISTRY BY EXEMPTING STATUTE, 1964-1973 ${ }^{a}$}

\begin{tabular}{lrrrrrrrrrr}
\hline Statutory basis for exemption & 1964 & 1965 & 1966 & 1967 & 1968 & 1969 & 1970 & 1971 & 1972 & 1973 \\
\hline Depression cartels & 2 & 2 & 16 & 1 & 0 & 0 & 0 & 0 & 9 & 2 \\
Rationalization cartels & 14 & 14 & 14 & 13 & 13 & 12 & 10 & 13 & 10 & 10 \\
Export cartels & 201 & 208 & 211 & 206 & 213 & 217 & 214 & 192 & 175 & 180 \\
Import cartels & 1 & 2 & 3 & 4 & 3 & 4 & 4 & 3 & 2 & 2 \\
$\quad \begin{array}{l}\text { Cartels under Medium and Small } \\
\quad \text { Enterprises Organization Act }\end{array}$ & 588 & 587 & 652 & 634 & 582 & 522 & 469 & 439 & 604 & 607 \\
$\quad$ Cartels under Environment & & & & & & & & & & \\
$\quad$ Sanitation Act & 106 & 122 & 123 & 123 & 123 & 123 & 123 & 123 & 123 & 123 \\
$\quad$ Cartels under Coastal Shipping & & & & & & & & & & \\
$\quad$ Association Act & 15 & 14 & 16 & 15 & 22 & 22 & 22 & 21 & 19 & 19 \\
$\quad$ Cartels under other statutes & 43 & 50 & 44 & 44 & 47 & 48 & 56 & 53 & 34 & 42 \\
$\quad$ Total & $\mathbf{9 7 0}$ & $\mathbf{9 9 9}$ & $\mathbf{1 0 7 9}$ & $\mathbf{1 0 4 0}$ & $\mathbf{1 0 0 3}$ & $\mathbf{9 4 8}$ & $\mathbf{8 9 8}$ & $\mathbf{8 4 4}$ & $\mathbf{9 7 6}$ & $\mathbf{9 8 5}$ \\
\hline
\end{tabular}

Source: Japanese Fair Trade Commission, Staff Office, The Antimonopoly Act of Japan (1973, p. 27). Reproduced from Caves and Uekusa (1976). Industrial Organization in Japan, The Brookings Institution, Washington, DC.

a Number in force in March of each year.

\section{Japan}

Competition policy in Japan has evolved over time since its inception under the United States military occupation in the late 1940s. The period which is relevant for developing countries is that from 1950-1973 when Japan was much more like a newlyindustrializing country than it is today. During this period Japan achieved extraordinarily fast economic growth, with manufacturing production rising at over 13 per cent per annum, GDP at 10 per cent a year and its share of world exports rising by a huge ten percentage points.

At this time, Japanese industrial policy, formulated by the Ministry of International Trade and Industry (MITI), had much the upper hand over the Fair Trade Commission (FTC), the competition watchdog. One of MITI's main objectives was to ensure a high rate of profitability and investment in Japanese industry. MITI was therefore always concerned with questions of "ruinous competition" leading to reduced profits and a lower propensity to invest. The Ministry thus officially sponsored a wide variety of cartels (including recession cartels, export cartels and technology cartels, to name a few), sequenced investment by firms and intervened in the exit and entry decisions of firms, all of which contributed to the high concentration ratios observed in the Japanese economy (see tables 1 and 12).

Some scholars, such as Caves and Uekusa (1976), have been stringent in their criticism of this weak competition policy arguing that it has imposed serious allocational inefficiencies on the Japanese economy.

However, MITI did not just thwart the FTC's codes and objectives, but it also implemented an industrial policy that encouraged contest-based competition between oligopolistic firms where the rewards were access to cheap credit and foreign exchange as well as, where necessary, protection from international competition. These rewards were contingent on relative performance either in export markets, technological development, or in introducing new products. The result was, as Odagiri (1994) and Porter (1990) note, that rivalry between firms in 
Japan was extremely intense. Indeed, as the persistency of profitability studies of the kind reviewed in Section II indicate, the intensity of competition in Japan's manufacturing sector has been greater than in United States manufacturing (Odagiri, 1994).

Thus, Japan followed a policy that promoted dynamic efficiency (in the sense of maximizing longterm growth of productivity) through an institutional structure that combined both co-operation and competition between firms. This policy has much to commend it to developing countries. It is fully in accord with the analytical considerations for an appropriate competition policy for developing countries outlined earlier and is also consistent with the latest advances in economic theory. ${ }^{25}$

\section{New concepts for competition policy for economic development}

In Singh and Dhumale (1999) we expressed serious misgivings about the WTO Working Group's analysis of competition policy for developing countries. It did not seem to us to meet one of the Group's chief objectives: to take the development dimension of competition policy fully into account. We came to the view that a discussion on competition policy and economic development in terms of the WTO concepts such as market access, reciprocity and national treatment was prejudicial to the interests of developing countries. To take the development dimension properly into account, it was essential to have new definitions and fresh concepts rather than to conduct the exercise in terms of the WTO terminology.

On the basis of the modern theory of industrial organization, as well as the history of competition policy in developed countries, Singh and Dhumale suggested that development-friendly competition policies need to have different objectives from those normally posited for advanced economies. Further, such policies also need to be specific to the stage of a country's economic and industrial development as well as its institutional and governance capacities. In relation to the WTO Working Group's tasks, this analysis suggested the following concepts to address the developmental dimensions of competition policy:

- the need to emphasise dynamic rather than static efficiency as the main purpose of competition policy from the perspective of economic development;
- the concept of "optimal degree of competition" (as opposed to maximum or perfect competition) to promote long term growth of productivity;

- the related concept of "optimal combination of competition and co-operation" to achieve fast long term economic growth;

- the critical significance of maintaining the private sector's propensity to invest at high levels and hence the need for a steady growth of profits; the latter in turn may necessitate government co-ordination of investment decisions so as to prevent over-capacity and falling profits;

- the concept of simulated competition, i.e., contests, for state support which can be as powerful as real market competition;

- the crucial importance of industrial policy to achieve the structural changes required for economic development; this in turn requires coherence between industrial and competition policies.

The development dimension is thus far from being fully taken into account by suggestions that all that developing countries need is a longer time frame to be able to implement the United States or United Kingdom type of competition policy. The special and different circumstances of developing countries and their developmental needs require a creative application of the concepts above to competition policy questions.

\section{Multilateral competition policy versus international competition authority}

At the WTO a number of advanced countries have been pressing developing countries to negotiate to make competition policy subject to that organization's multilateral disciplines, so as to ensure "fair play" and "level playing fields" between countries.

Developing countries have been opposed to such proposals. Their formal stance has been to suggest that as many of them have no experience of competition policy, they are not in a position to be able to enter into negotiations on these matters. The real reason for developing countries' opposition is 
that they do not wish any new disciplines to be included in the WTO agreements because of the provision of cross-sanctions: a violation in one area may be penalized in another by the complaining country (if the complaint is held to be justified). Until the Doha meeting developing countries took the view that the Uruguay Round Agreements, that established the WTO, needed to be properly reviewed for their impact on economic development before undertaking a new round of tariff cutting or starting negotiations on new subjects such as competition policy and the multilateral agreement on investment. However, after the Doha Ministerial meeting developing countries may find it difficult to maintain such a stance for long.

It may be interesting to observe that there has been an ironic reversal of roles here. In the past, developing countries were in favour of multilateral action to restrict business practices of the large multinational companies. At the insistence of developing countries the United Nations General Assembly in December 1980 adopted, by Resolution 35/63 a "Set of Multilaterally Agreed Equitable Principles and Rules for the Control of Restrictive Business Practices". The "Set" is fairly comprehensive in scope and covers a wide range of restrictive business practices by multinationals, including the abuse of their dominant positions whether achieved through mergers and acquisitions or joint ventures. ${ }^{26}$ At that time developing countries were in favour of making SET legally binding. This, however, was not acceptable to developed countries. Today the position is the other way around with advanced countries seeking a binding multilateral agreement through the WTO and developing countries opposing it.

Proponents of a multilateral agreement on competition policy have put forward the following arguments in its favour:

- It would be helpful to developing countries as it would enable them to restrain anti-competitive behaviour and cartelization by large, advanced country corporations.

- It may help to bring the TRIPS agreement under multilateral competition disciplines. Maskus and Lahouel (2000) suggest that the possible abuse of intellectual property rights, as well as parallel imports, could be regulated by a multilaterally agreed competition policy.

- Stiglitz (1999) suggests that if there were a new multilateral competition policy agreement this would help to blunt the potency of anti-dumping laws by bringing them into the normal framework of predation under competition laws. The predation test is much stricter than the anti-dumping measures which countries have been using under the WTO. ${ }^{27}$

- A multilateral competition policy will help foster competition both nationally and internationally, from which it is suggested that developing countries would greatly benefit. Perroni and Whalley (1998) quantify the potential gains of developing countries from the introduction of disciplines on competition,

the potential gains for developing countries could be large, perhaps in the region of 5-6 per cent of national income. This would make a competition policy negotiation of potentially more significance to developing countries than the whole of the trade disciplines achieved in the Uruguay Round. (Perroni and Whalley, 1998, p. 493). ${ }^{28}$

These gains would include those stemming from the replacement of anti-dumping measures by competition law, reduction of mark-ups of foreign suppliers and reduced concentration in domestic markets.

There are, however, powerful arguments against multilateral disciplines from the perspective of developing countries. The first is that a multilateral agreement on competition policy, to be development friendly, must be highly flexible allowing each country to determine its competition policy for itself on the basis of the country's needs and circumstances. This implies that if the cost-benefit analysis for a particular country shows there is no gain from it, the country need not have a competition policy at all.

Critics of a multilateral competition policy also suggest that a main motivation for developed countries to seek a competition policy agreement is for reasons of market access to developing countries. Developed countries would like to have, in addition to an agreement on competition policy, an international agreement on foreign direct investment (FDI). Under the latter, large advanced country multinationals would be permitted to invest anywhere they like in any quantity and at any time without any let or hindrance from developing country governments. In addition, once established, the multinationals would have "national treatment", i.e. be treated the same as national firms. An ambitious multilateral agreement on these issues would accord multinationals 
equal treatment in both pre and post-establishment phases.

However, such an agreement would be seriously prejudicial to economic development. In a detailed analysis of FDI as a source of long-term finance for developing countries, Singh (2001a) has argued that unless it is adequately regulated by their governments, in the particular circumstances of these countries, where they are subject to frequent internal and external shocks, it would lead to short and long-term financial fragility. To avoid this fragility, it is necessary for developing country governments to control (a) the timing of the FDI; (b) the total amount of FDI; as well as (c) the selection of large projects by multinationals. These measures are needed to ensure that there is no mismatch of the time profile of a country's foreign exchange inflows and outflows. Such time inconsistency can lead to a liquidity crisis, which as the experience of Asian economic crisis shows, may degenerate into solvency problems with ultimately devastating consequences for the real economy. ${ }^{29}$

Multinationals often complain that there is no "level playing field" between them and the national corporations which are government supported; hence, the multinationals demand for "national treatment". However, the actual situation is quite the opposite; the playing fields are tilted heavily in favour of multinationals who have considerable market power in markets for outputs as well as inputs. The current international merger movement is making these fields more unequal even from the perspective of the large developing country corporations.

The mechanical application of the WTO principle of "national treatment" in these circumstances would clearly lead to perverse results that would both harm economic development in developing countries as well as lead to global economic inefficiency. The magnitude of the latter would be determined by the extent to which the multinationals financial advantage over domestic firms arises from market power rather than from genuine economies of scale.

To provide a simple illustration, it should be perfectly legitimate for a developing country competition authority to allow large domestic firms to merge so that they can go some way toward competing on more equal terms with multinationals from abroad. Even if the amalgamating national firms are on the horizontal part of the L-shaped static cost curve, bigger size may still promote dynamic efficiency for the reason that firms need to achieve a minimum threshold size to finance their own $R \& D$ activities. The competition authority may therefore quite reasonable deny national treatment to the multinationals and prohibit their merger activity (because they are already large enough to achieve either static or dynamic economies of scale in this sense). In these circumstances, a violation of the doctrine of national treatment is likely to be beneficial both to economic development and to competition.

In view of these serious limitations of multilateral competition policy it is essential to look for alternative means of international co-operation on this subject. This is because, as argued earlier, even if developing countries had development friendly national competition policies, they would still need international assistance to restrain anti-competitive conduct of dominant multinationals as well as to limit the adverse effects of mega-mergers associated with the merger movement of the 1990s. The best way, it seems to me, to provide such help would be through an International Competition Authority. The characteristics and responsibilities of this Authority would include the following:

- It would be charged with maintaining fair competition in the world economy and keeping the markets contestable by ensuring that the barriers-to-entry to late industrializers are kept at low levels.

- Analogous to the social welfare objectives of the European Commission, the proposed International Authority would be asked to pay attention to the special needs of the developing countries, to competitive opportunities for small and medium sized firms, to facilitate transfer of technology to developing countries and to ensure fair prices and fair distribution of wealth.

- It would have the authority to scrutinise megamergers and to deter the mega-firms from abusing their dominant position.

- Again on the European Union model, the International Competition Authority would be concerned mainly with cross-border or international aspects of the workings of competition. Below the authority, at a national level, the member countries would have their own national competition policies.

- For good administrative and practical reasons, references to the competition authority would only be permissible in case of anti-competitive behaviour by corporations above a certain size. 
The size criterion would normally keep even most large developing country corporations outside the direct purview of the competition authority.

- In relation to the international merger movement, the authority would attempt to limit growth by merger by large multinationals under its purview. They would be allowed to merge provided they divest themselves of a subsidiary of equal value. This would mean that multinationals would not be able to grow by mergers, but they could expand through organic growth or green-field investment. It would not stop them from taking over other firms provided they were willing to sever a similar sized subsidiary.

- In the light of the extended discussion of the international merger movement in Section III, the main merits of this proposal are as follows. As mergers, on average, do not appear to improve economic efficiency, and the megamergers have the potential of increasing market dominance and reducing contestability, discouraging such mergers would therefore enhance global competition and global economic efficiency while at the same time being distributionally more equitable.

- The governance of the ICA would have proper representation of developing countries and would not be dominated by developed countries.

Although international co-operation on competition policy, in the form outlined above, would be of particular benefit to developing countries, it also has useful features to assist the large multinational corporations. The International Competition Authority would for example be able to provide multinationals under its purview with unambiguous decisions on mergers and other competition related matters. Instead of being subject to the often conflicting decisions of many different jurisdictions (e.g., the United States, the European Union, Japan, and overtime countries like India and China) International Competition Authority's rulings would prevail overall national and regional jurisdiction. ${ }^{30}$

There is no illusion that an international agreement of the above kind would immediately be acceptable to advanced countries. Nevertheless, it indicates the nature of economic arrangements in this area which would best serve developmental needs of poor countries. It may, however, be helpful to pro- ceed to the establishment of the ICA in stages. At the first stage, the authority may have no coercive powers, but simply be able to monitor and to report on abuses of dominant market positions, on mergers, and the authority's other competition objectives. ${ }^{31}$ Such monitoring would itself be beneficial to developing countries as it would provide them with information on cartels and on market power abuses of multinationals. Developing countries would find it difficult to acquire such information otherwise. With the experience gained from this kind of limited international co-operation, nations can, over time, work towards greater co-operation by giving ICA the necessary powers to enforce its rules.

There is finally the question whether ICA should nevertheless be an integral part of the WTO or should it be a stand-alone authority. In addition to the reasons mentioned earlier in the discussion of the multilateral competition policy, there are also other considerations that would suggest the latter would be the better option. This is in part because questions of competition policy go much beyond those related to international trade. Further, WTO does not have the expertise to be the world's "FTC". Moreover, the primary objectives of competition policy tend to be rather different from those of the promotion of free trade through measures such as market access and national treatment. Since, as indicated above, the latter concepts are not very helpful to developing countries it would be best to keep the two institutions (the WTO and the ICA) separate.

\section{Conclusion}

The main points of this essay have been presented in the Abstract. Its central message is to suggest that developing countries at the WTO are faced with a serious difficulty in discussions on competition policy as well as on other similar issues as long as the whole discourse is expressed in terms of the WTO concepts and language. These are inadequate to reflect the developmental concerns of emerging countries. Developing countries need to develop the appropriate language and concepts within which their concerns can be properly articulated. Hopefully this paper has made a small contribution in that direction.

The Preamble to the WTO notes that "trade and economic endeavour should be conducted with a view to raising the standards of living, ensuring full employment and a large and steadily growing vol- 
ume of real income and effective demand". It is further stated that "there is need for positive efforts designed to ensure that developing countries, and especially the least-developed among them, secure a share in the growth in international trade commensurate with the needs of their economic development" (quoted in Rodrik, 2001). Full employment and economic development are not only the ultimate goals of the WTO; these have also been repeatedly endorsed by the international community. In 1995, 117 Heads of State or Government attending the Copenhagen Social Summit endorsed the Copenhagen Declaration, which put primary emphasis on the promotion of full employment and poverty reduction. More recently, similar declaration have been made at the Millennium Summit at the United Nations and other fora. Indeed, the right to a decent living has virtually acquired the status of a universal human right.

If experience and analysis show that the primary goals of the WTO are being harmed rather than helped by specific measures such as TRIMS, or the equal application to all countries of a particular procedural principle such as national treatment, it is the latter which should be changed. It is the primary goals rather than the procedural rules of an international organization that should dominate especially as the former are widely endorsed by the world community as a whole.

In this spirit the paper has put forward a proposal for a development friendly International Competition Authority in order to control anti-competitive conduct of the world's large multinational corporations (above a certain threshold of size) as well as to control their propensity to grow by takeovers and mergers. In order to maintain contestability and efficiency of international markets it is proposed that the large multinationals should be allowed to take over another company only if they sell off a subsidiary of similar value. Thus, even the largest multinationals are not stopped from growing provided they expand their size by green-field investment. Neither are they stopped from taking over other firms provided they are able to sell off equal value subsidiaries, i.e. they cannot grow by mergers or take-overs. It is argued here that these institutional arrangements would both be more efficient as well as more equitable compared with the present situation. It is, however, recognized that the advanced countries are not yet ready to cede sovereignty for such close international co-operation. The evolution towards the establishment of the ICA could, therefore occur in stages. As a first step the
Authority could be entrusted only with fact-finding and monitoring anti-competitive behaviour and threats to the contestability of international markets. This could evolve over time into deeper North-South co-operation and the full-fledged establishment of the ICA according to the principles outlined in the paper.

\section{Notes}

1 This WTO Working Group on Trade and Competition Policy (WGTCP) has been meeting under the chairmanship of Professor Frédéric Jenny for the last four years. Their work will be commented upon later in the paper.

2 The United States takes a more measured stance. The United States Trade Representative's Fact Sheet summarising the results of the Doha ministerial noted in relation to competition policy that a two-stage "modest" negotiation was agreed upon. The first stage would seek clarification of "core principles", including transparency, non-discrimination and procedural fairness. At the second stage the "timing and specific content" of the negotiations will be decided.

3 The account of the Doha ministerial meeting in this paragraph and the following one comes from Bridges (International Centre for Trade and Sustainable Development), Year 5, No. 9, November/December 2001, p. 6.

4 Apart from the WTO, the CUTS Centre for International Trade, Economics and Environment reports that competition policy is the on the agenda of the proposed Free Trade Area of the Americas (FTAA) as well as the European Union / Africa, Caribbean, Pacific Grouping (EU / ACP).

5 For the structural analysis of the Asian crisis see for example Greenspan (1998), Phelps (1999), and IMF (1998). The structural analysis of the Asian crisis is of course neither necessarily accurate nor universally accepted. For a strong rebuttal see, Singh (1999) and Singh and Weisse (1999); for alternative analyses see among others Radelet and Sachs (1998); Feldstein (1998, 2002); Stiglitz (1999).

6 See de Soto (1989).

7 The first bias arises from the fact that the data in table 2 pertain to size of plants rather than enterprises. This bias would, however, understate relatively the small firms' contribution to the economies of developing countries. This is because there are likely to be more multi-plant enterprises in developed than in developing countries. Second, the data by and large consider only the formal sector. The informal sector in developing countries is typically very considerably larger than that in advanced countries. This bias would also therefore operate in the same direction as the first.

8 A distinction is often made between competition law and competition policy - the latter being a wider concept encompassing elements of industrial policy among other things (see for example Hoekman and Kostecki (2001)). Here, formal competition policy is used in the narrow sense. The broader concept employed here is that of industrial policy.

9 These estimates are reported in World Bank (2002).

10 For a fuller discussion of these issues see World Bank (1993), and Amsden (2001). For a theoretical analysis, see Nalebuff and Stiglitz (1983b). 
11 This is a rather different conception of competition from that involved in the Arrow-Debreu formulation of general equilibrium in a decentralized market economy. In this conception, a competitive equilibrium exists under certain specified conditions that leads to a Pareto-optimal allocation of resources. However, the notion of competition described in the text is rather different: it is concerned with the common-sense understanding of competition as an incentive to elicit maximum individual or organization effort.

12 See further Amsden and Singh (1994), and Laffont (1998).

13 See further Vickers (1994) and Nickell (1996).

14 There is a vast literature on this subject. See Amsden (1989), Rodrik (1994), Singh (1995) and Wade (1990) among others.

15 The classic reference here is Piore and Sabel (1984). See also Best (1990).

16 See Pollit (1999) for a useful review of the literature on the subject.

17 The United Kingdom had a similarly large merger wave roughly around the same time. Parenthetically, the best historical data on mergers is available for the United States and the United Kingdom. The two countries have similar institutions and corporate laws which allow useful comparisons between them. International comparisons involving other countries are always more difficult because of differences in corporate law as well as the definition of what constitutes a "merger". See further Hughes and Singh (1980).

18 Best (1990), p. 104.

19 For recent reviews of the literature see Mueller (1997) and Tichy (2001).

20 A few studies have found a small increase in profitability after mergers. However, 90 per cent of studies have found either no change or reduced profits.

21 For a general discussion and quantitative analysis of the cartels, which have been detected and presented during the last two decades, see Evenett, Levenstein and Suslow (2001).

22 On the incidence of cartels in the 1930s and the post-war period, see Mason (1946) and Scherer (1994). On the reasons for the rise in mergers and take-overs in the postwar period, see Singh $(1992,1993)$.

23 The Economist (2002).

24 As Stiglitz rightly points out, one needs to distinguish between a Suharto and a Mobuto.

25 According to Audretsch, Baumol and Burke (2001), the dynamic efficiency perspective of competition policy and modern theoretical analysis requires consideration of issues such as the appropriate ease of entry; appropriate inter-firm coordination; innovation, trade and monopoly power; anti-competitive innovation; monopoly in innovative markets; and price discrimination when $R \& D$ costs are substantial and continuing. In other words, a host of dynamic factors must be analyzed. This is the authors' recommendation for an appropriate competition policy in advanced countries. What MITI did in Japan during its period of high growth was to adapt such considerations to their particular circumstances.

26 Similarly in 1986, the OECD issued guidelines concerning restrictive business practices by multinationals. Under the guidelines, which again were advisory rather than legally enforceable, multinational enterprises were enjoined to refrain from a wide range of anti-competitive activities including abuses of intellectual property rights, predatory behaviour, competition reducing acquisitions, etc. (See further, OECD 1986; Scherer, 1994).
27 Stiglitz presents a recent report on United States antidumping cases which suggests that, if these had been subject to the equivalent United States competition policy standard of predation, more than 90 per cent of them would have failed. (Stiglitz, 1999).

28 Quoted in Correa (1999).

29 These arguments for permitting developing countries to be able to monitor and to regulate FDI flows are further complemented by considerations of technology transfer and spillover benefits. Research shows that both of those occur best when FDI is carefully regulated and fits well into a country's development program. See further Singh (2001a); Singh (forthcoming).

30 For the difficulties involved for corporate decision making as a consequences of overlapping jurisdictions of competition authorities of different countries, see "Trade and Competition: Towards a global response". http:// trade-info.cec.eu.int/europa/2001newround/com.htm.

31 Scherer, 1994, makes a similar point in relation to his proposal for an international agreement on competition policy.

\section{References}

Amsden A (2001). The Rise of "The Rest": Challenges to the West from Late-Industrializing Economies. Oxford University Press, New York.

Amsden A (1989). Asia's Next Giant: South Korea and Late Industrialization, Oxford University Press, New York.

Amsden A and Singh A (1994). "The Optimal Degree of Competition and Dynamic Efficiency in Japan and Korea", European Economic Review, Vol. 28, pp. 941-951.

Audretsch D, Baumol W and Burke A (2001). "Competition policy in dynamic markets", International Journal of Industrial Organization, Vol. 19, No. 5, April, pp. 613-634.

Aw B, Chung S and Roberts M (2002). "Productivity, Output, and Failure: A Comparison of Taiwanese and Korean Manufacturers", NBER Working Paper No. 8766, February, Cambridge, Mass.

Baker J (1999). "Developments in Antitrust Economics", Journal of Economic Perspectives, Vol. 13, No. 1, Winter, pp. 181-194.

Baumol W (2001). "When is inter-firm coordination beneficial? The case of innovation", International Journal of Industrial Organization, Vol. 19, pp. 727-737.

Best M (1990). The New Competition: Institutions of Industrial Restructuring, Harvard University Press, Cambridge, Mass.

Caves R and Uekusa M (1976). Industrial Organisation in Japan, The Brookings Institution, Washington, DC.

Correa CM (1999). "Competition Law and Development Policies", paper presented at the Zurich Seminar on Issues of International Competition Law, University of Zurich, 8-10 July.

CUTS (2000). Centre for International Trade, Economics and Environment, "Globalisation, Competition Policy and International Trade Negotiations: Considerations for Developing Countries". Monographs on Investment and Competition Policy, \#4.

de Soto H (1989). The Other Path: The Invisible Revolution in the Third World, Harper and Row, New York.

The Economist (2002). "Cartels: Fixing for a Fight", 20 April, pp. 71-72.

Evenett SJ, Levenstein MC and Suslow VY (2001). "International Cartel Enforcement: Lessons from the 1990s", World Economy, Vol. 24, 9, pp. 1221-1245. 
Feldstein M (1998). "Trying to do too much”, Financial Times, 3 March.

Feldstein M (2002). "Economic and Financial Crises in Emerging Market Economies: Overview of Prevention and Management". NBER Working Paper 8837, March, Cambridge, Mass.

Glen J, Lee K and Singh A (2001). "Persistence of profitability and competition in emerging markets", Economics Letters, Vol. 72, pp. 247-253.

Glen J, Lee K and Singh A (2002). "Corporate Profitability and the Dynamics of Competition in Emerging Markets: A Time Series Analysis", unpublished, University of Cambridge.

Goddard J and Wilson J (1999). "The persistence of profit: a new empirical interpretation", International Journal of Industrial Organization, Vol. 17, pp. 663-687.

Gort M (1969). "An Economic Disturbance Theory of Mergers”, Quarterly Journal of Economics, Vol. 83, pp. 624-642.

Greenspan A (1998). Testimony before the Committee on Banking and Financial Services, United States House of Representatives, 30 January.

Gugler K, Mueller D, Burcin Yurtoglu B and Zulehner C (2001). "The Effects of Mergers: An International Comparison". Paper presented at UNIP conference, Vienna, December.

Hoekman BM and Kostecki MM (2001). The Political Economy of the World Trading System. Oxford.

Holmstrom B and Kaplan S (2001). "Corporate Governance and Merger Activity in the United States: Making Sense of the 1980s and 1990s", Journal of Economic Perspectives, Vol.15, No. 2, Spring, pp. 121-144.

Hughes A and Singh A (1980). "Mergers, concentration and competition in advanced capitalist economies: An international perspective", in Mueller D, ed., The Determinants and Effects of Mergers, pp. 1-26. Oelgeschlager, Gunn and Hain, Cambridge, Mass.

IMD, The International Institute for Management Development (2002). World Competitiveness Yearbook, 2002. Lausanne.

IMF (1998). "The Asian Crisis: Causes and Cures", Finance and Development, Vol. 35, No. 2, June. International Monetary Fund, Washington, DC.

Laffont JJ (1998). "Competition, Information, and Development", Annual World Bank Conference on Development Economics, 1998, pp. 237-257.

Mason ES (1946). Controlling World Trade: Cartels and Commodity Agreements. McGraw-Hill.

Maskus, K and Lahouel M (2000). "Competition Policy and Intellectual Property Rights in Developing Countries", World Economy, pp. 595-611.

Mueller D (1997). "Merger Policy in the United States: A Reconsideration", Review of Industrial Organization, Vol. 12, Nos. 5-6, pp. 655-685.

Nalebuff B and Stiglitz J (1983a). "Information, Competition, and Markets", The American Economic Review, Vol. 73, No. 2, pp. 278-283.

Nalebuff B and Stiglitz J (1983b). "Prizes and incentives: towards a general theory of compensation and competition", Bell Journal of Economics, Vol. 14, Spring, pp. 21-43.

Nickell S (1996). "Competition and Corporate Performance", Journal of Political Economy, Vol. 104, No. 4, pp. 724746.

Odagiri H (1994). Growth Through Competition, Competition Through Growth: Strategic Management and the Economy in Japan. Oxford University Press, New York.

OECD (1986). The OECD Guidelines for Multinational Enterprises, Organisation for Economic Co-operation and Development, Paris.
Perroni C and Whalley J (1998). "Competition policy and the developing countries", in Thomas H and Whalley J eds., Uruguay Round Results and the Emerging Trade Agenda: Quantitative-based Analyses from the Development Perspective. UNCTAD, New York and Geneva.

Phelps ES (1999). "The Global Crisis of Corporatism", Wall Street Journal, 25 March.

Piore M and Sabel C (1984). The Second Industrial Divide, Basic Books, New York.

Pollitt M (1999). "A Survey of the Liberalisation of Public Enterprises in the UK since 1979", DAE Working Paper, No. 9901, Department of Applied Economics, University of Cambridge.

Porter M (1990). The Competitive Advantage of Nations, Macmillan Press, London.

Radelet S and Sachs J (1998). "The East Asian Financial Crisis: Diagnosis, Remedies, Prospects", Brookings Papers on Economic Activity, The Brookings Institution, Washington, DC.

Rodrik D (2001). "The global governance of trade: As if development really mattered", UNDP Background Paper, New York.

Rodrik D (1994). "King Kong Meets Godzilla: The World Bank and The East Asian Miracle", in Fishlow A et al., Miracle or Design? Lessons from the East Asian Experience, Overseas Development Council, Policy Essay No. 11. Washington DC.

Shleifer A and Summers LH (1988). "Breach of Trust in Hostile Takeovers", in Auerbach AJ, ed., Corporate Takeovers: Causes and Consequences, National Bureau of Economic Research, University of Chicago Press.

Scherer FM (1994). Competition Policies for an Integrated World Economy, The Brookings Institution, Washington, DC.

Singh A (forthcoming). "Capital Account Liberalization, Free Long-Term Capital Flows, Financial Crises and Economic Development". Forthcoming in Eastern Economic Journal.

Singh A (2001a). "Foreign Direct Investment and International Agreements: A South Perspective", T.R.A.D.E. Occasional Paper, No. 6, October. South Centre, Geneva.

Singh A (2001b). Statement made to the German Parliament's Study Commission on "Globalisation of the World Economy - Challenges and Responses", 14 May.

Singh A (1999). "Asian Capitalism' and the financial crisis”, in Michie J and Grieve-Smith J, eds., Global Instability. Routledge, London.

Singh A and Dhumale R (1999). "Competition Policy, Development and Developing Countries", T.R.A.D.E. Working Papers, No. 7, November, South Centre (www.southcentre.org/ publications/index.htm), Geneva. Subsequently published in Arestis, Baddeley PM and McCombie J (2001), What Global Economic Crisis?, pp. 122-145. Palgrave, Hampshire.

Singh A (1998). "Liberalization, the stock market and the market for corporate control: A bridge too far for the Indian economy?", in Ahluwalia IJ and Little IMD, eds., India's Economic Reforms and Development: Essays for Manmohan Singh. Oxford University Press, New Delhi.

Singh A (1995). Corporate Financial Patterns in Industrialising Economies: A Comparative International Study. Technical Paper 2, International Finance Corporation, World Bank, Washington, DC.

Singh A (1993). "Regulation of Mergers: A New Agenda", in Sugden R, ed., Industrial Economic Regulation: A Framework and Exploration, pp. 141-158. Routledge, London.

Singh A (1992). "Corporate Takeovers", in Eatwell J, Milgate $\mathrm{M}$ and Newman P, eds., The New Palgrave Dictionary of Money and Finance, pp. 480-486. Macmillan, London and New York. 
Singh A (1975). "Takeovers, Economic Natural Selection and the Theory of the Firm: Evidence from the Post-War UK Experience", Economic Journal, Vol. 85, No. 339, September.

Singh, A. 1971. Takeovers: Their Relevance to the Stock Market and the Theory of the Firm, Cambridge University Press, Cambridge.

Singh A. and Weisse B (1999) "The Asian Model: A Crisis Foretold?" International Social Science Journal, No. 160, pp. 203-215.

Stigler GJ (1950). "Monopoly and oligopoly by merger", American Economic Review, Supplement, May.

Stiglitz J (2000). "Two Principles for the Next Round or, How to Bring Developing Countries in from the Cold", World Economy, pp. 437-454.

Stiglitz J (1999). "Reforming the Global Financial Architecture: Lessons from Recent Crises", Journal of Finance, 54(4), pp. 1508-22.

Stiglitz J (1998). "Restoring the Asian Miracle", Wall Street Journal Europe, 3 February, p. 4.

Telser L (1987). A Theory of Efficient Cooperation and Competition, Cambridge University Press, Cambridge.

Tichy G (2001). "What do we know about success and failure of mergers?", paper presented at UNIP conference in Vienna, December.

Tybout J (2000). "Manufacturing Firms in Developing Countries: How Well Do They Do, and Why?", Journal of Economic Literature, Vol. XXXVIII, March, pp. 11-44.
UNCTAD (1999). Trade and Development Report,1999. United Nations publication, Sales No. E.99.II.D.1. New York and Geneva.

UNCTAD (2001). World Investment Report, 2001. United Nations publication, Sales No. E.01.II.D.12. New York and Geneva.

UNCTAD (2000). World Investment Report, 2002. United Nations publications, Sales No. E.00.D.20. New York and Geneva.

Vickers J (1994). Concepts of Competition, Inaugural Lecture as Drummond Professor of Political Economy before the University of Oxford. Clarendon Press, Oxford.

Wade R (1990). Governing the Market: Economic Theory and the Role of Government in East Asian Industrialization, Princeton University Press, Princeton, NJ.

Waring G (1996). "Industry differences in the persistence of firm-specific returns", American Economic Review, No. 86, pp. 1253-1265.

World Bank (1991). World Development Report: The Challenges of Development, World Bank and Oxford University Press, Washington, DC and New York.

World Bank (1993). The East Asian Miracle: Economic Growth and Public Policy, Oxford University Press, New York.

World Bank (2002). World Development Report: Building Institutions for Markets, World Bank and Oxford University Press, Washington, DC and New York. 
G-24 Discussion Paper Series*

Research papers for the Intergovernmental Group of Twenty-Four on International Monetary Affairs

\begin{tabular}{|c|c|c|c|}
\hline No. 17 & April 2002 & F. LÓPEZ-DE-SILANES & The Politics of Legal Reform \\
\hline No. 16 & January 2002 & $\begin{array}{l}\text { Gerardo ESQUIVEL and } \\
\text { Felipe LARRAÍN B. }\end{array}$ & $\begin{array}{l}\text { The Impact of G-3 Exchange Rate Volatility on Developing } \\
\text { Countries }\end{array}$ \\
\hline No. 15 & December 2001 & $\begin{array}{l}\text { Peter EVANS and } \\
\text { Martha FINNEMORE }\end{array}$ & $\begin{array}{l}\text { Organizational Reform and the Expansion of the South's } \\
\text { Voice at the Fund }\end{array}$ \\
\hline No. 14 & September 2001 & Charles WYPLOSZ & $\begin{array}{l}\text { How Risky is Financial Liberalization in the Developing } \\
\text { Countries? }\end{array}$ \\
\hline No. 13 & July 2001 & José Antonio OCAMPO & Recasting the International Financial Agenda \\
\hline No. 12 & July 2001 & $\begin{array}{l}\text { Yung Chul PARK and } \\
\text { Yunjong WANG }\end{array}$ & $\begin{array}{l}\text { Reform of the International Financial System and } \\
\text { Institutions in Light of the Asian Financial Crisis }\end{array}$ \\
\hline No. 11 & April 2001 & Aziz Ali MOHAMMED & The Future Role of the International Monetary Fund \\
\hline No. 10 & March 2001 & JOMO K.S. & $\begin{array}{l}\text { Growth After the Asian Crisis: What Remains of the East } \\
\text { Asian Model? }\end{array}$ \\
\hline No. 9 & February 2001 & Gordon H. HANSON & Should Countries Promote Foreign Direct Investment? \\
\hline No. 8 & January 2001 & $\begin{array}{l}\text { Ilan GOLDFAJN and } \\
\text { Gino OLIVARES }\end{array}$ & $\begin{array}{l}\text { Can Flexible Exchange Rates Still "Work" in Financially } \\
\text { Open Economies? }\end{array}$ \\
\hline No. 7 & December 2000 & Andrew CORNFORD & $\begin{array}{l}\text { Commentary on the Financial Stability Forum's Report } \\
\text { of the Working Group on Capital Flows }\end{array}$ \\
\hline No. 6 & August 2000 & $\begin{array}{l}\text { Devesh KAPUR and } \\
\text { Richard WEBB }\end{array}$ & $\begin{array}{l}\text { Governance-related Conditionalities of the International } \\
\text { Financial Institutions }\end{array}$ \\
\hline No. 5 & June 2000 & Andrés VELASCO & $\begin{array}{l}\text { Exchange-rate Policies for Developing Countries: What } \\
\text { Have We Learned? What Do We Still Not Know? }\end{array}$ \\
\hline No. 4 & June 2000 & Katharina PISTOR & $\begin{array}{l}\text { The Standardization of Law and Its Effect on Develop- } \\
\text { ing Economies }\end{array}$ \\
\hline No. 3 & May 2000 & Andrew CORNFORD & $\begin{array}{l}\text { The Basle Committee's Proposals for Revised Capital } \\
\text { Standards: Rationale, Design and Possible Incidence }\end{array}$ \\
\hline No. 2 & May 2000 & T. Ademola OYEJIDE & $\begin{array}{l}\text { Interests and Options of Developing and Least- } \\
\text { developed Countries in a New Round of Multilateral } \\
\text { Trade Negotiations }\end{array}$ \\
\hline
\end{tabular}

No. 1 March 2000

Arvind PANAGARIYA

The Millennium Round and Developing Countries: Negotiating Strategies and Areas of Benefits

\footnotetext{
* G-24 Discussion Paper Series are available on the website at: http://www.unctad.org. Copies of G-24 Discussion Paper Series may be obtained from the Publications Assistant, Macroeconomic and Development Policies Branch, Division on Globalization and Development Strategies, United Nations Conference on Trade and Development (UNCTAD), Palais des Nations, CH-1211 Geneva 10, Switzerland; E-mail: mdpb-ed.assistant@unctad.org.
} 